\title{
Extracellular Calcium-Dependent Modulation of Endothelium Relaxation in Rat Mesenteric Small Artery: The Role of Potassium Signaling
}

\author{
Lise Hangaard, ${ }^{1}$ Peter B. Jessen, ${ }^{1}$ Dmitrii Kamaev, ${ }^{1}$ \\ Christian Aalkjaer, ${ }^{1,2}$ and Vladimir V. Matchkov ${ }^{1}$ \\ ${ }^{1}$ MEMBRANES, Department of Biomedicine, Health, Aarhus University, 8000 Aarhus, Denmark \\ ${ }^{2}$ Department of Biomedicine, University of Copenhagen, Copenhagen, Denmark
}

Correspondence should be addressed to Vladimir V. Matchkov; vvm@fi.au.dk

Received 5 June 2015; Revised 11 August 2015; Accepted 16 August 2015

Academic Editor: Richardt G. Landgraf

Copyright (c) 2015 Lise Hangaard et al. This is an open access article distributed under the Creative Commons Attribution License, which permits unrestricted use, distribution, and reproduction in any medium, provided the original work is properly cited.

The nature of NO- and COX-independent endothelial hyperpolarization (EDH) is not fully understood but activation of smalland intermittent-conductance $\mathrm{Ca}^{2+}$-activated $\mathrm{K}^{+}$channels $\left(\mathrm{SK}_{\mathrm{Ca}}\right.$ and $\left.\mathrm{IK}_{\mathrm{Ca}}\right)$ is important. Previous studies have suggested that the significance of $\mathrm{IK}_{\mathrm{Ca}}$ depends on $\left[\mathrm{Ca}^{2+}\right]_{\text {out }}$. Also it has been suggested that $\mathrm{K}^{+}$is important through localized $\left[\mathrm{K}^{+}\right]_{\text {out }}$ signaling causing activation of the $\mathrm{Na}^{+}, \mathrm{K}^{+}$-ATPase and inward-rectifying $\mathrm{K}^{+}$channels $\left(\mathrm{K}_{\mathrm{ir}}\right)$. Here we tested the hypothesis that the modulating effect of $\left[\mathrm{Ca}^{2+}\right]_{\text {out }}$ on the EDH-like response depends on $\left[\mathrm{K}^{+}\right]_{\text {out }}$. We addressed this possibility using isometric myography of rat mesenteric small arteries. When $\left[\mathrm{K}^{+}\right]_{\text {out }}$ was $4.2 \mathrm{mM}$, relaxation to acetylcholine $(\mathrm{ACh})$ was stronger at $2.5 \mathrm{mM}\left[\mathrm{Ca}^{2+}\right]_{\text {out }}$ than at $1 \mathrm{mM}\left[\mathrm{Ca}^{2+}\right]_{\text {out }}$. Inhibition of $\mathrm{IK}_{\mathrm{Ca}}$ with TRAM34 suppressed the relaxations but did not change the relation between the relaxations at the low and high $\left[\mathrm{Ca}^{2+}\right]_{\text {out }}$. This $\left[\mathrm{Ca}^{2+}\right]_{\text {out }}$-dependence disappeared at $5.9 \mathrm{mM}\left[\mathrm{K}^{+}\right]_{\text {out }}$ and in the presence of ouabain or $\mathrm{BaCl}_{2}$. Our results suggest that $\mathrm{IK}_{\mathrm{Ca}}$ are involved in the localized $\left[\mathrm{K}^{+}\right]_{\text {out }}$ signaling which acts through the $\mathrm{Na}^{+}, \mathrm{K}^{+}$-ATPase and $\mathrm{K}_{\mathrm{ir}}$ channels and that the significance of this endothelium-dependent pathway is modulated by $\left[\mathrm{Ca}^{2+}\right]_{\text {out }}$.

\section{Introduction}

The importance of the arterial endothelium for controlling vascular resistance is well-established [1]. Several factors are released from the endothelium and relax the adjacent smooth muscle cells. In addition to $\mathrm{NO}$ and prostaglandins, the endothelium is able to produce vasodilatation through a third pathway, which is particularly important in small arteries and arterioles [2]. The third pathway is the endotheliumdependent hyperpolarization (EDH) of smooth muscles, which is present after the inhibition of $\mathrm{NO}$ and prostaglandin production $[3,4]$. The mechanisms proposed for EDH are direct spreading of hyperpolarizing current via myoendothelial gap junctions or release of diffusible factors(s) $(\operatorname{EDHF}(\mathrm{s}))$. The relative contribution of these two pathways and the nature of the EDHFs vary among species and vascular beds, blood vessel caliber, ageing, and diseases, as well as between different experimental conditions and laboratories $[3,5]$. It is unlikely that a single factor accounts for EDHF and multiple diffusible factors, including $\mathrm{K}^{+}$, $\mathrm{NO}, \mathrm{HNO}$, epoxyeicosatrienoic acids, $\mathrm{H}_{2} \mathrm{~S}, \mathrm{H}_{2} \mathrm{O}_{2}$, and vasoactive peptides, have been suggested.

A key element in the EDH pathway supported by most studies is activation of endothelial small- and intermittentconductance $\mathrm{Ca}^{2+}$-activated $\mathrm{K}^{+}$channels $\left(\mathrm{SK}_{\mathrm{Ca}}\right.$ and $\mathrm{IK}_{\mathrm{Ca}}$, resp.) upon agonist- or shear stress-induced increase of endothelial cell calcium $\left(\left[\mathrm{Ca}^{2+}\right]_{\text {in }}\right)[6]$. Although activation of both $\mathrm{SK}_{\mathrm{Ca}}$ and $\mathrm{IK}_{\mathrm{Ca}}$ channels can lead to vasodilation, their contribution to the $\mathrm{EDH}$ is different [3-5]. $\mathrm{SK}_{\mathrm{Ca}}$ channels are distributed homogeneously over the endothelial cell membrane and respond to increase of $\left[\mathrm{Ca}^{2+}\right]_{\text {in }}[7,8]$. Hyperpolarization produced by the $\mathrm{SK}_{\mathrm{Ca}}$ channels is believed 
to spread via myoendothelial gap junctions to smooth muscle cells. This original hypothesis is, however, modified [5, 9] based on the observation that $\mathrm{SK}_{\mathrm{Ca}}$-dependent hyperpolarization can be blocked not only by apamin, a $\mathrm{SK}_{\mathrm{Ca}}$ channel inhibitor, but also by $\mathrm{Ba}^{2+}$ in concentrations specifically blocking the inward-rectifying $\mathrm{K}^{+}$channels $\left(\mathrm{K}_{\mathrm{ir}}\right)$ [10]. It has been suggested that $\mathrm{K}^{+}$efflux through the opened $\mathrm{SK}_{\mathrm{Ca}}$ channels might increase the local $\left[\mathrm{K}^{+}\right]_{\text {out }}$ and consequently open $\mathrm{K}_{\mathrm{ir}}$ channels. In this model the localized $\left[\mathrm{K}^{+}\right]_{\text {out }}$ increase amplifies endothelial hyperpolarization generated by $\mathrm{SK}_{\mathrm{Ca}}$ channel opening [5].

In contrast, the $\mathrm{IK}_{\mathrm{Ca}}$ channels are localized in endothelial cell projections near the adjacent smooth muscle cells [11] where $\mathrm{K}^{+}$efflux through these channels increases $\left[\mathrm{K}^{+}\right]_{\text {out }}$ by about $6 \mathrm{mM}[12]$, which has been called a " $\mathrm{K}^{+}$cloud" [13]. The " $\mathrm{K}^{+}$cloud" may hyperpolarize smooth muscle cells via activation of the $\mathrm{Na}^{+}, \mathrm{K}^{+}$-ATPase and $\mathrm{K}_{\mathrm{ir}}$ channels $[11,14]$. This hypothesis is supported by ouabainand $\mathrm{Ba}^{2+}$-sensitive hyperpolarization of smooth muscles in endothelium-denuded arteries with few $\mathrm{mM}$ elevation of $\left[\mathrm{K}^{+}\right]_{\text {out }}[12]$. Both these $\mathrm{K}^{+}$sensors, that is, the Na,K-ATPase and the $\mathrm{K}_{\mathrm{ir}}$ channels, are expressed in smooth muscle cells $[11,15]$ although their importance varies between vascular beds [5].

How endothelial excitation leads to differentiated activation of $\mathrm{SK}_{\mathrm{Ca}} / \mathrm{IK}_{\mathrm{Ca}}$ channels remains unclear but this may be modulated by $\left[\mathrm{Ca}^{2+}\right]_{\text {out }}$ via the $\mathrm{Ca}^{2+}$-sensing receptor (CaSR) [16]. Thus, changes in $\left[\mathrm{Ca}^{2+}\right]_{\text {out }}$ may switch the EDH signaling between being predominantly $\mathrm{SK}_{\mathrm{Ca}^{-}}$/myoendothelial gap junction-dependent and being $\mathrm{IK}_{\mathrm{Ca}}-/$ " $\mathrm{K}^{+}$cloud" dependent pathways.

Based on these considerations we hypothesized that modulation of the EDH-like response by $\left[\mathrm{Ca}^{2+}\right]_{\text {out }}$ is dependent on $\left[\mathrm{K}^{+}\right]_{\text {out }}$ and tested the importance of $\mathrm{IK}_{\mathrm{Ca}}, \mathrm{Na}^{+}, \mathrm{K}^{+}$ATPase, and $K_{i r}$ channels for these effects of $\left[\mathrm{Ca}^{2+}\right]_{\text {out }}$ and $\left[\mathrm{K}^{+}\right]_{\text {out }}$.

\section{Methods}

All experiments were approved by and conducted with permission from the Animal Experiments Inspectorate of the Danish Ministry of Food, Agriculture and Fisheries. Rats were euthanized by $\mathrm{CO}_{2}$-inhalation.

In vitro functional experiments were performed on rat mesenteric small artery. Rat mesentery was dissected and placed in ice-cold physiological salt solution (PSS). Thirdorder branches of the rat mesenteric small artery were dissected. The cleaned arterial segments were mounted in an isometric wire myograph (Danish Myo Technology A/S, Denmark) as described previously [17]. The myograph chamber was heated to $37^{\circ} \mathrm{C}$, while the PSS was constantly aerated with $5 \% \mathrm{CO}_{2}$ in air. Force was recorded with a PowerLab 4/25-Chart7 acquisition system (ADInstruments Ltd., New Zealand) and converted to wall tension by dividing force with double segment length. Contractile concentrationresponse relationships were constructed by cumulative noradrenaline concentrations (NA: $0.1-30 \mu \mathrm{M}$ ). The relaxation concentration-response relationships were constructed by cumulative addition of acetylcholine (ACh) $(0.01-10 \mu \mathrm{M})$ to the arteries preconstricted with $6 \mu \mathrm{M}$ noradrenaline. A maximum of three concentration-response relaxations were made on one artery.

The $4.2 \mathrm{mM}\left[\mathrm{K}^{+}\right]$-containing PSS composition was (in $\mathrm{mM}) 119.00 \mathrm{NaCl}, 3.0 \mathrm{KCl}, 1.18 \mathrm{KH}_{2} \mathrm{PO}_{4}, 1.17 \mathrm{MgCl}_{2}, 25.0$ $\mathrm{NaHCO}_{3}, 0.026$ EDTA, and 5.5 glucose, gassed with $5 \% \mathrm{CO}_{2}$ in air and adjusted to $\mathrm{pH}$ 7.4. The $5.9 \mathrm{mM}\left[\mathrm{K}^{+}\right]$-containing PSS composition was (in $\mathrm{mM}$ ) $119.00 \mathrm{NaCl}, 4.7 \mathrm{KCl}, 1.18$ $\mathrm{KH}_{2} \mathrm{PO}_{4}, 1.17 \mathrm{MgSO}_{4}, 25.0 \mathrm{NaHCO}_{3}, 0.026$ EDTA, and 5.5 glucose, gassed with $5 \% \mathrm{CO}_{2}$ in air and adjusted to $\mathrm{pH}$ 7.4. Either $1 \mathrm{mM}$ or $2.5 \mathrm{mM} \mathrm{CaCl}_{2}$ was added to the PSS as indicated. All chemicals were obtained from Sigma-Aldrich (Brondby, Denmark). Drugs were applied 15 minutes before experiment.

Statistical analyses were performed using GraphPad Prism 5 (Graph Pad Software Inc., USA). Data are expressed as mean values \pm SEM. Concentration-response curves were fitted to experimental data using four-parameter, nonlinear regression curve fitting. From these curves, $\mathrm{pD}_{2}$ (the concentration required to produce a half-maximal response) and maximal response were derived and compared using an extra sum-of-squares $F$ test. $t$-test was used where appropriate. $P<$ 0.05 was considered significant. $n$ refers to number of rats.

\section{Results}

The sensitivities $\left(\mathrm{pD}_{2}\right)$ and maximal responses to noradrenaline were the same with all four experimental solutions, that is, $1 \mathrm{mM}$ and $2.5 \mathrm{mM}\left[\mathrm{Ca}^{2+}\right]_{\text {out }}$ and $4.2 \mathrm{mM}$ or $5.9 \mathrm{mM}\left[\mathrm{K}^{+}\right]_{\text {out }}$ (Figure $1(\mathrm{a})$ ). Thus, the preconstriction levels in relaxation experiments were the same in all experimental conditions. Inhibition of the $\mathrm{IK}_{\mathrm{Ca}}$ channels with $10 \mu \mathrm{M}$ TRAM34 did not affect the concentration-response relationship to noradrenaline (Figure $1(\mathrm{~b})$ ). Neither $\mathrm{pD}_{2}$ nor maximal contractile responses were significantly affected by TRAM34.

Arteries preconstricted with $6 \mu \mathrm{M}$ noradrenaline were relaxed with cumulative addition of ACh (Figure 2). The preconstriction remained stable in time-control experiments where only vehicle was applied (Figures 2(a) and 2(b)).

In the $4.2 \mathrm{mM}\left[\mathrm{K}^{+}\right]_{\text {out }}$ containing solution the relaxation was more pronounced when $\left[\mathrm{Ca}^{2+}\right]_{\text {out }}$ was $2.5 \mathrm{mM}$ in comparison with $1 \mathrm{mM}\left[\mathrm{Ca}^{2+}\right]_{\text {out }}$ (Figures $2(\mathrm{a})$ and $2(\mathrm{c})$ ). This was associated with a higher sensitivity to $\mathrm{ACh}, \mathrm{pD}_{2} 7.16 \pm 0.07$ versus $6.45 \pm 0.09(P<0.01, n=8)$. When $\left[\mathrm{K}^{+}\right]_{\text {out }}$ in the bath solution was elevated to $5.9 \mathrm{mM}$, no difference between concentration-response curves at $1 \mathrm{mM}$ and $2.5 \mathrm{mM}\left[\mathrm{Ca}^{2+}\right]_{\text {out }}$ was observed (Figures 2(b) and $2(\mathrm{~d})$ ) $; \mathrm{pD}_{2}$ were $7.06 \pm 0.08$ and $7.23 \pm 0.05(n=6)$, respectively.

Preincubation of arteries with $100 \mu \mathrm{M} \mathrm{L}-\mathrm{NAME}$ and $3 \mu \mathrm{M}$ indomethacin significantly suppressed the relaxation to ACh in the presence of both $4.2 \mathrm{mM}$ and $5.9 \mathrm{mM}\left[\mathrm{K}^{+}\right]_{\text {out }}$. Importantly, these inhibitors shifted the concentration-response curves to the right (Figure 2). However, when the bath solution contained $4.2 \mathrm{mM}\left[\mathrm{K}^{+}\right]_{\text {out }}$ the relaxation was still more pronounced in the presence of $2.5 \mathrm{mM}$ compared to $1 \mathrm{mM}\left[\mathrm{Ca}^{2+}\right]_{\text {out }}$ (Figures $2(\mathrm{a})$ and $2(\mathrm{c})$ ). When $\left[\mathrm{K}^{+}\right]_{\text {out }}$ was $5.9 \mathrm{mM}$, no difference in the relaxations at different $\left[\mathrm{Ca}^{2+}\right]_{\text {out }}$ was seen (Figures 2(b) and 2(d)). 


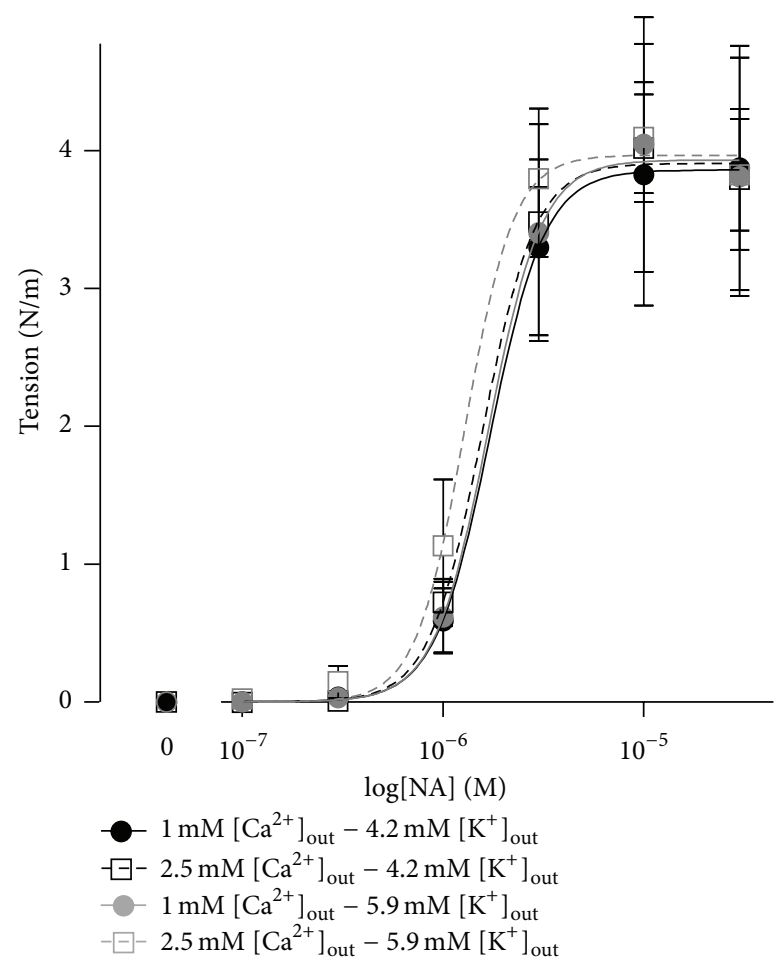

(a)

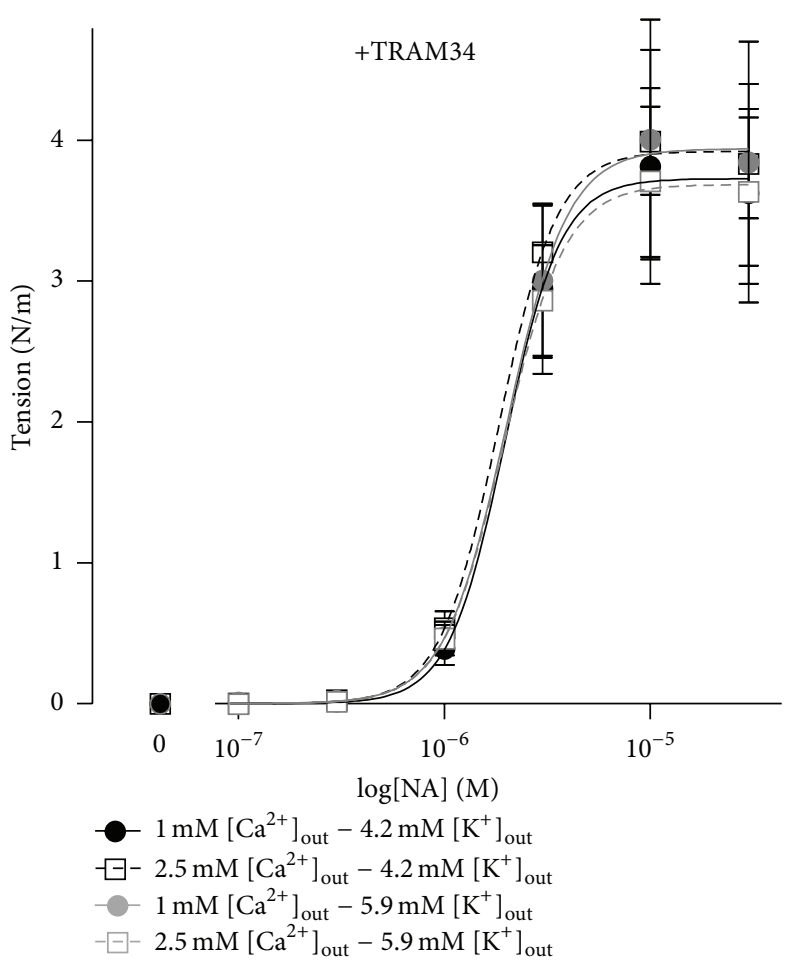

(b)

FIGURE 1: Concentration-dependent contractions to noradrenaline (NA) of rat mesenteric small arteries were not different in the presence of $1 \mathrm{mM}$ and $2.5 \mathrm{mM}\left[\mathrm{Ca}^{2+}\right]_{\text {out }}$. The contractions were also the same in solutions with $4.2 \mathrm{mM}\left[\mathrm{K}^{+}\right]_{\text {out }}$ and with $5.9 \mathrm{mM}\left[\mathrm{K}^{+}\right]_{\text {out }}$. Preincubation with $10 \mu \mathrm{M}$ TRAM34 was without significant effect on the contractile responses ((a) versus (b)). $n=6$.

Repeated relaxations to cumulative addition of ACh in the presence of L-NAME and indomethacin were similar (Figure 3), demonstrating that there was no time-dependent effect on relaxation to ACh.

To assess the importance of $\mathrm{IK}_{\mathrm{Ca}}$ for the effect of $\left[\mathrm{Ca}^{2+}\right]_{\text {out }}$ we repeated the experiments in the presence of $1 \mu \mathrm{M}$ TRAM34. TRAM34 suppressed the relaxations to ACh in the presence of L-NAME and indomethacin (Figures 4(a) and $4(\mathrm{~b}))$. In the $4.2 \mathrm{mM}\left[\mathrm{K}^{+}\right]_{\text {out }}$ containing solution the relaxations in the presence of TRAM34 were still stronger at $2.5 \mathrm{mM}$ than at $1 \mathrm{mM}\left[\mathrm{Ca}^{2+}\right]_{\text {out }}$. When $\left[\mathrm{K}^{+}\right]_{\text {out }}$ was $5.9 \mathrm{mM}$ no difference in relaxations at $1 \mathrm{mM}$ and $2.5 \mathrm{mM}\left[\mathrm{Ca}^{2+}\right]_{\text {out }}$ was seen in the presence of TRAM34 (Figure 4(c)).

In spite of similar changes in the areas under the curve, TRAM34 affected the concentration-response curves differently at $1 \mathrm{mM}$ and $2.5 \mathrm{mM}\left[\mathrm{Ca}^{2+}\right]_{\text {out }}$ when $\left[\mathrm{K}^{+}\right]_{\text {out }}$ was $4.2 \mathrm{mM}$. TRAM34 reduced the sensitivity to $\mathrm{ACh}$ at $2.5 \mathrm{mM}\left[\mathrm{Ca}^{2+}\right]_{\text {out }}$ (Figure 4(d)) but suppressed the maximal relaxation at $1 \mathrm{mM}\left[\mathrm{Ca}^{2+}\right]_{\text {out }}$ (Figure $4(\mathrm{e})$ ).

At $5.9 \mathrm{mM}\left[\mathrm{K}^{+}\right]_{\text {out }}$ TRAM34 had the same effect on $\mathrm{pD}_{2}$ to $\mathrm{ACh}$ in the presence of $1 \mathrm{mM}$ and $2.5 \mathrm{mM}\left[\mathrm{Ca}^{2+}\right]_{\text {out }}$ (Figure $4(\mathrm{~d})$ ). No effect of TRAM34 on maximal relaxation was seen in the presence of $5.9 \mathrm{mM}\left[\mathrm{K}^{+}\right]_{\text {out }}$ (Figure $4(\mathrm{e})$ ).

Preincubation of arteries with L-NAME, indomethacin, TRAM34, and apamin completely inhibited the AChdependent relaxations independently of $\left[\mathrm{K}^{+}\right]_{\text {out }}$ and $\left[\mathrm{Ca}^{2+}\right]_{\text {out }}$ (not shown, $n=6-8$ ).
To assess the importance of the $\mathrm{Na}^{+}, \mathrm{K}^{+}$-ATPase for the effect of $\left[\mathrm{Ca}^{2+}\right]_{\text {out }}$ we repeated the experiments in the presence of $10 \mu \mathrm{M}$ ouabain. Ouabain suppressed the AChinduced relaxation in the presence of $100 \mu \mathrm{M}$ L-NAME and $3 \mu \mathrm{M}$ indomethacin (Figure 5). Ouabain suppressed the relaxation more in the presence of $4.2 \mathrm{mM}\left[\mathrm{K}^{+}\right]_{\text {out }}$ than in the presence of $5.9 \mathrm{mM}\left[\mathrm{K}^{+}\right]_{\text {out }}$ (Figure $5(\mathrm{c})$ ). In the presence of ouabain there was no difference between the areas under curves in the presence of $1 \mathrm{mM}$ and $2.5 \mathrm{mM}\left[\mathrm{Ca}^{2+}\right]_{\text {out }}$ at any $\left[\mathrm{K}^{+}\right]_{\text {out }}$. Importantly, the effects of ouabain on the sensitivity to ACh and the maximal relaxations were independent of $\left[\mathrm{Ca}^{2+}\right]_{\text {out }}$ (Figures 5(d) and 5(e)). However, ouabain suppressed the maximal relaxations at $4.2 \mathrm{mM}\left[\mathrm{K}^{+}\right]_{\text {out }}$ more than in the presence of $5.9 \mathrm{mM}\left[\mathrm{K}^{+}\right]_{\text {out }}$ (Figure $5(\mathrm{e})$ ).

To assess the importance of $K_{\text {ir }}$ for the effect of $\left[\mathrm{Ca}^{2+}\right]_{\text {out }}$ we repeated the experiments in the presence of $30 \mu \mathrm{M} \mathrm{BaCl}_{2}$. $\mathrm{BaCl}_{2}$ inhibited the ACh-dependent relaxation only when the bath solution contained $4.2 \mathrm{mM}\left[\mathrm{K}^{+}\right]_{\text {out }}$ (Figure 6(a)). In the presence of $\mathrm{BaCl}_{2}$ no differences between the areas under the curve at $1 \mathrm{mM}$ and $2.5 \mathrm{mM}\left[\mathrm{Ca}^{2+}\right]_{\text {out }}$ were seen (Figure $6(\mathrm{c})$ ). No effect of $\mathrm{BaCl}_{2}$ on the relaxations at $5.9 \mathrm{mM}\left[\mathrm{K}^{+}\right]_{\text {out }}$ was seen.

The effect of $\mathrm{BaCl}_{2}$ at $4.2 \mathrm{mM}\left[\mathrm{K}^{+}\right]_{\text {out }}$ was dependent on $\left[\mathrm{Ca}^{2+}\right]_{\text {out }} \cdot \mathrm{BaCl}_{2}$ suppressed the sensitivity to $\mathrm{ACh}$ only when $\left[\mathrm{Ca}^{2+}\right]_{\text {out }}$ was $2.5 \mathrm{mM}$ (Figure 6(d)). In contrast, the maximal relaxations were similarly suppressed in the presence of both $1 \mathrm{mM}$ and $2.5 \mathrm{mM}\left[\mathrm{Ca}^{2+}\right]_{\text {out }}$ (Figure 6(e)). 


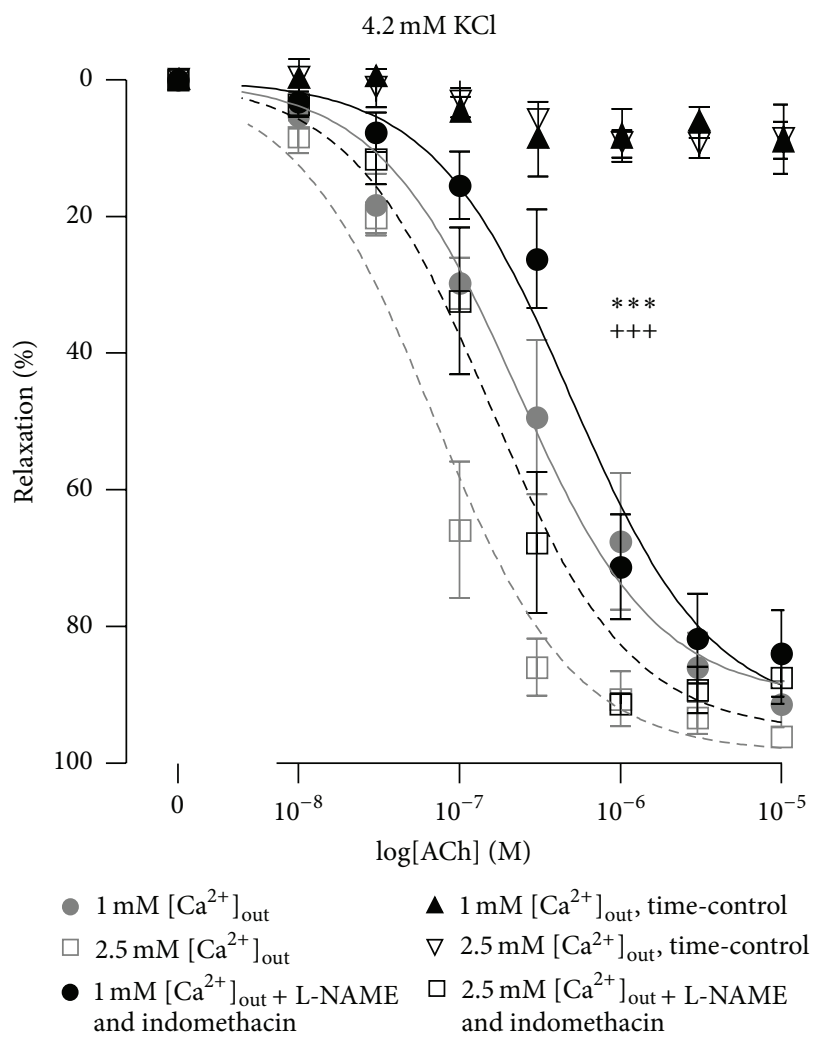

(a)

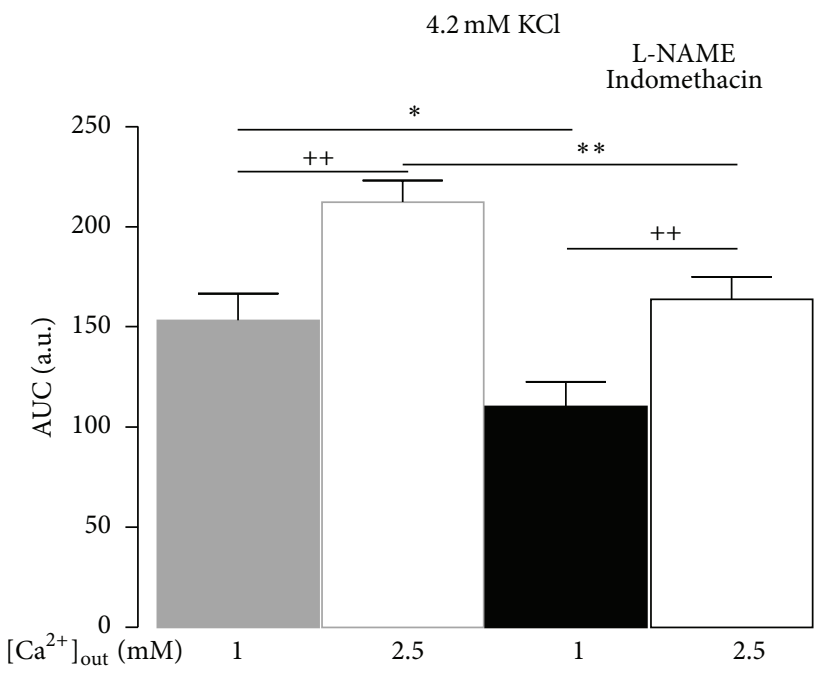

(c)

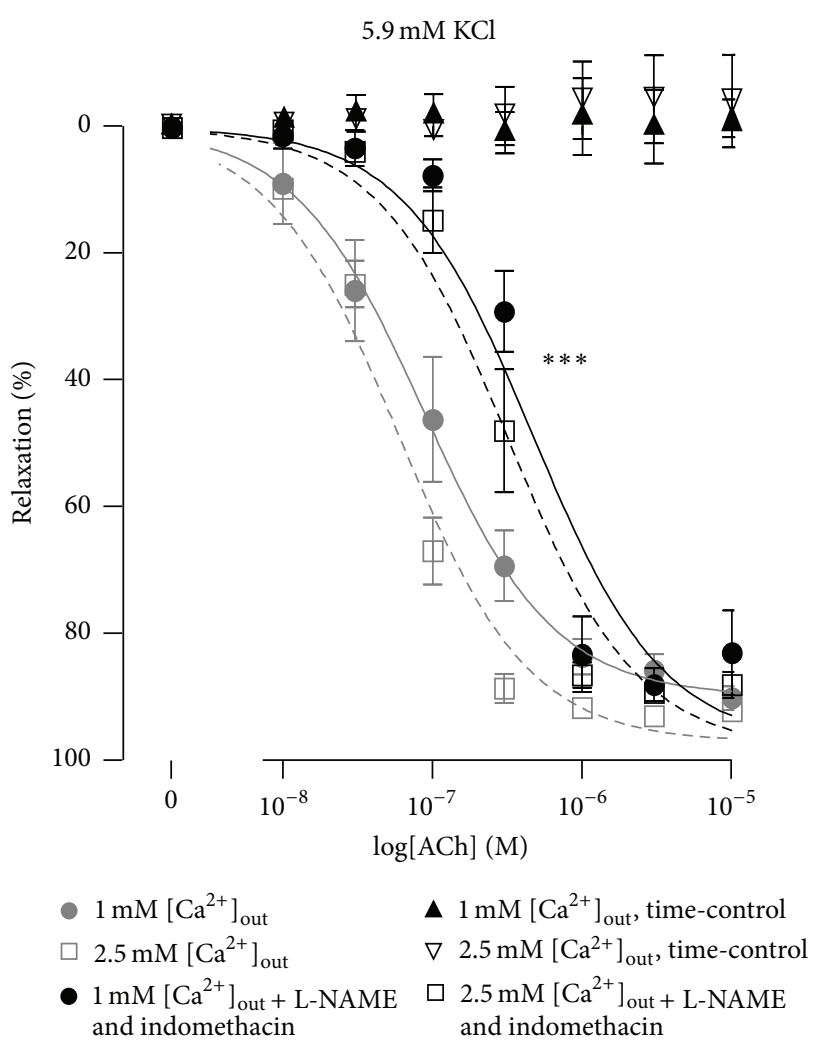

(b)

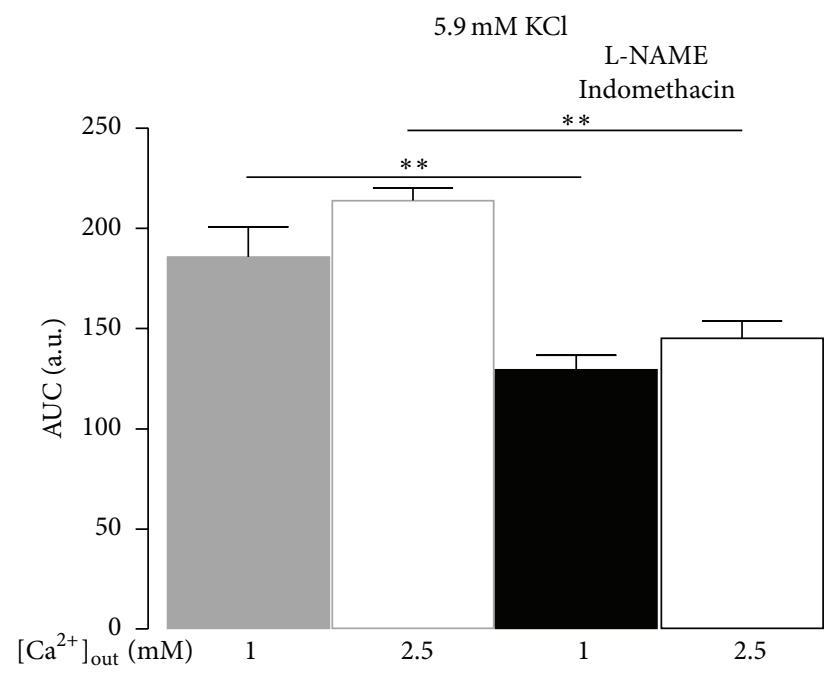

(d)

FIgURE 2: The concentration-dependent relaxation to ACh in the bath solutions containing either $4.2 \mathrm{mM}((\mathrm{a}) n=8)$ or $5.9 \mathrm{mM}((\mathrm{b}) n=6)$ $\left[\mathrm{K}^{+}\right]_{\text {out }}$. In the time-control experiments only the vehicle was supplied $(n=2-4)$. Responses were compared under control conditions and after preincubation with $100 \mu \mathrm{M}$ L-NAME and $3 \mu \mathrm{M}$ indomethacin. (c) and (d) show the areas under curve (AUC) for the concentrationresponses shown in (a) and (b). ++ and +++ indicate $P<0.01$ and 0.001 for responses in the presence of $1 \mathrm{mM}\left[\mathrm{Ca}^{2+}\right]_{\text {out }}$ versus $2.5 \mathrm{mM}$ $\left[\mathrm{Ca}^{2+}\right]_{\text {out }} * *$ and $* * *$ indicate $P<0.01$ and 0.001 for responses before and after application of L-NAME and indomethacin.

\section{Discussion}

We have studied the $\left[\mathrm{Ca}^{2+}\right]_{\text {out }}$-dependent modulation of EDH-like signaling and the role of $\mathrm{IK}_{\mathrm{Ca}}$ and the $\left[\mathrm{K}^{+}\right]_{\text {out }}$ sensors, that is, the $\mathrm{Na}^{+}, \mathrm{K}^{+}$-ATPase and $\mathrm{K}_{\mathrm{ir}}$ channels, for this modulation.
4.1. $\left[\mathrm{Ca}^{2+}\right]_{\text {out }}$ and the $I K_{\mathrm{Ca}}$ Channels. We found that an elevation of $\left[\mathrm{Ca}^{2+}\right]_{\text {out }}$ from 1 to $2.5 \mathrm{mM}$ increases the relaxation to ACh. This was also seen after the blockade of NOand prostaglandin-dependent pathways. This is in accordance with the previous observations where wall tension 


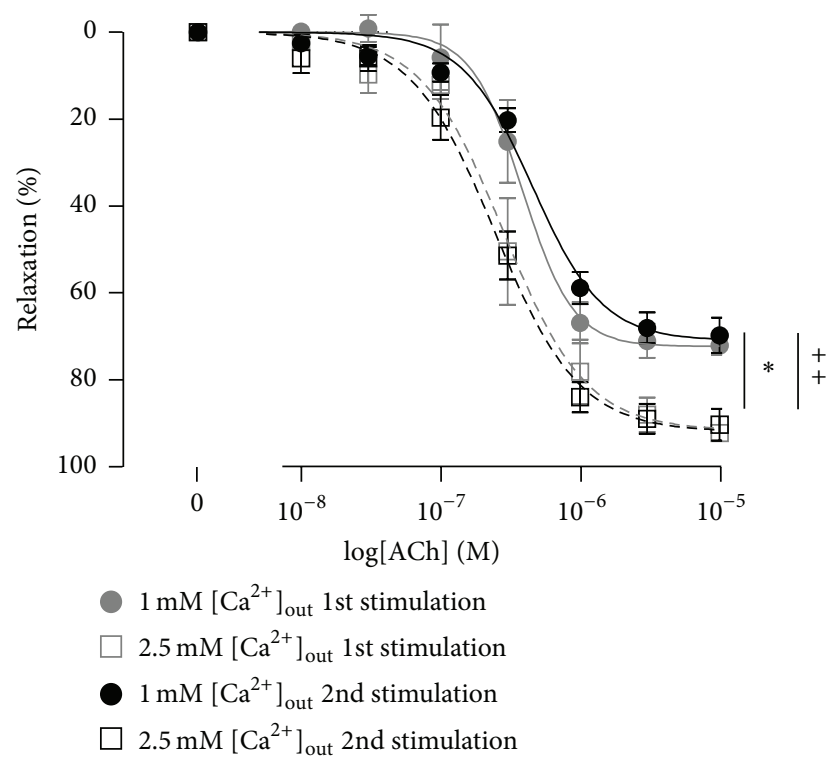

FIGURE 3: Repeated ACh concentration-relaxation curves in the presence of $100 \mu \mathrm{M}$ L-NAME and $3 \mu \mathrm{M}$ indomethacin $(n=5)$. Relaxations were first performed in the presence of either $1 \mathrm{mM}$ or $2.5 \mathrm{mM}\left[\mathrm{Ca}^{2+}\right]_{\text {out }}$; the bath solution was then replaced with either $2.5 \mathrm{mM}$ or $1 \mathrm{mM}\left[\mathrm{Ca}^{2+}\right]_{\text {out }}$. This protocol was repeated once more. * indicates $P<0.05$ for $1 \mathrm{mM}$ versus $2.5 \mathrm{mM}\left[\mathrm{Ca}^{2+}\right]_{\text {out }}$ for the 1st stimulations; ++ indicates $P<0.05$ for $1 \mathrm{mM}$ versus $2.5 \mathrm{mM}$ $\left[\mathrm{Ca}^{2+}\right]_{\text {out }}$ for the 2 nd stimulations.

and membrane potential were measured [11]. We did not measure membrane potential, but the sensitivity of NOand prostaglandin-independent relaxation to TRAM34 and apamin suggests that this effect was mediated via an EDHlike pathway. The effects of two relatively low $(1 \mathrm{mM})$ and high $(2.5 \mathrm{mM})\left[\mathrm{Ca}^{2+}\right]_{\text {out }}$ concentrations were compared, because $\mathrm{IK}_{\mathrm{Ca}}$ channel-dependent relaxation has previously been shown to differ strikingly at these two concentrations of $\mathrm{Ca}^{2+}[11]$.

Although the high $\left[\mathrm{Ca}^{2+}\right]_{\text {in }}$ in activated endothelial cells activates both $\mathrm{SK}_{\mathrm{Ca}}$ and $\mathrm{IK}_{\mathrm{Ca}}$ channels, the relative importance of $\mathrm{SK}_{\mathrm{Ca}}$ and $\mathrm{IK}_{\mathrm{Ca}}$ has been suggested to depend on $\left[\mathrm{Ca}^{2+}\right]_{\text {out }}$ in the myoendothelial space $[7,8]$. It has been suggested that $\left[\mathrm{Ca}^{2+}\right]_{\text {out }}$ is sensed by the G-protein-coupled CaSR [18] which can modulate the $\mathrm{IK}_{\mathrm{Ca}}$ channel-dependent $\mathrm{EDH}$ in the vascular wall $[11,16,19]$. It was therefore tempting to speculate that the effect of $\left[\mathrm{Ca}^{2+}\right]_{\text {out }}$ changes seen in the present study could be explained by changes in the $\mathrm{IK}_{\mathrm{Ca}}$ activity. However, after inhibition of $\mathrm{IK}_{\mathrm{Ca}}$ with TRAM34 there was still a modulating effect of $\left[\mathrm{Ca}^{2+}\right]_{\text {out }}$. This suggests that the modulatory role of $\left[\mathrm{Ca}^{2+}\right]_{\text {out }}$ cannot be limited to an effect on the $\mathrm{IK}_{\mathrm{Ca}}$ channels.

Part of the $\mathrm{Ca}^{2+}$ effect may, however, be via the $\mathrm{IK}_{\mathrm{Ca}}$ channels since TRAM34 affected the ACh concentrationresponse curves differently at the two $\left[\mathrm{Ca}^{2+}\right]_{\text {out }}$ concentrations. This contrasts with a previous report [11] where TRAM34 eliminated the modulating effect of $\left[\mathrm{Ca}^{2+}\right]_{\text {out }}$ on ACh relaxations. However, the actual values obtained in the previous study [11] were rather similar to those found in the present study; in the presence of TRAM34 the maximal relaxation tended to be less with $1 \mathrm{mM}$ compared to $2.5 \mathrm{mM}$ $\left[\mathrm{Ca}^{2+}\right]_{\text {out }}[11]$. Thus, the effect of $\left[\mathrm{Ca}^{2+}\right]_{\text {out }}$-CaSR signaling on the $\mathrm{IK}_{\mathrm{Ca}}$ channels likely explains a part of the effect of $\left[\mathrm{Ca}^{2+}\right]_{\text {out }}$ on EDH, possibly via modulation of $\left[\mathrm{Ca}^{2+}\right]_{\text {in }}[20$, 21].

4.2. $\left[\mathrm{Ca}^{2+}\right]_{\text {out }}$ and the $\mathrm{Na}^{+}, \mathrm{K}^{+}-A T P s e / K_{\text {ir }}$ Channels. Simultaneous inhibition of $\mathrm{SK}_{\mathrm{Ca}}$ channels with apamin and $\mathrm{IK}_{\mathrm{Ca}}$ channels with TRAM34 resulted in complete inhibition of endothelium-dependent relaxation. In contrast to TRAM34, the inhibitory effect of apamin was larger at $2.5 \mathrm{mM}\left[\mathrm{Ca}^{2+}\right]_{\text {out }}$. It is therefore possible that $\left[\mathrm{Ca}^{2+}\right]_{\text {out }}$ may also modify the activity of the $\mathrm{SK}_{\mathrm{Ca}}$ channels. Another possibility is that $\left[\mathrm{Ca}^{2+}\right]_{\text {out }}$ has an effect downstream for activation of the $\mathrm{SK}_{\mathrm{Ca}} / \mathrm{IK}_{\mathrm{Ca}}$ channels.

A downstream effect of $\left[\mathrm{Ca}^{2+}\right]_{\text {out }}$ might include an effect on the two $\mathrm{K}^{+}$sensors, the ouabain-sensitive $\mathrm{Na}^{+}, \mathrm{K}^{+}$-ATPase and $K_{\text {ir }}$ channels, which are also known to be involved in EDH signaling [5]. To address this possibility we assessed the effect of inhibition of the $\mathrm{Na}^{+}, \mathrm{K}^{+}$-ATPase with ouabain $[11,22]$ and the effect of inhibition of the $K_{\text {ir }}$ channels with $\mathrm{Ba}^{2+}[23,24]$. Both these interventions reduced the relaxation to $\mathrm{ACh}$ as expected. Importantly, in the presence of both ouabain and $\mathrm{Ba}^{2+}\left[\mathrm{Ca}^{2+}\right]_{\text {out }}$ had no effect on the ACh response. This might suggest that the effect of $\left[\mathrm{Ca}^{2+}\right]_{\text {out }}$ is mediated via the $\mathrm{Na}$, $\mathrm{K}$-ATPase and $\mathrm{K}_{\mathrm{ir}}$ channels.

Interestingly, inhibition of either the $\mathrm{Na}^{+}, \mathrm{K}^{+}$-ATPase or $\mathrm{K}_{\text {ir }}$ channels caused more than $50 \%$ inhibition of the relaxation at $4.2 \mathrm{mM}\left[\mathrm{K}^{+}\right]_{\text {out }}$. If these $\mathrm{K}^{+}$sensors act strictly in parallel, this is surprising. A possibility is that these transporters interact functionally and support the activity of each other. Thus, it has previously been shown that the $\mathrm{Na}^{+}, \mathrm{K}^{+}$ATPase associates functionally with some $\mathrm{K}^{+}$channels, for example, the ATP-dependent $\mathrm{K}^{+}$channels $\left(\mathrm{K}_{\text {ATP }}\right)$ [25]. $\mathrm{K}^{+}$ ions leaving the cell through the $\mathrm{K}^{+}$channels have been shown to supply the $\mathrm{Na}^{+}, \mathrm{K}^{+}$-ATPase with $\mathrm{K}^{+}$even in $\left[\mathrm{K}^{+}\right]_{\text {out }}{ }^{-}$ free media [26], while the $\mathrm{Na}^{+}, \mathrm{K}^{+}$-ATPase activity provides a gradient for the ionic current through the $\mathrm{K}^{+}$channels [25]. A similar functional interaction has previously been reported in the heart [27] and pancreas [28]. It is possible that the $\mathrm{Na}^{+}, \mathrm{K}^{+}$-ATPase and the $\mathrm{K}_{\mathrm{ir}}$ channels may also interact functionally to short-circuit the membrane $\mathrm{K}^{+}$transport.

Both the $\mathrm{Na}^{+}, \mathrm{K}^{+}$-ATPase and $\mathrm{K}_{\mathrm{ir}}$ channels are expressed in the smooth muscle cells, although they may also be present in the endothelial cells $[11,19,29]$. The effect of $\left[\mathrm{Ca}^{2+}\right]_{\text {out }}$ might therefore be mediated via either smooth muscle or endothelial cells. Some studies reported that the effect of $\mathrm{Ba}^{2+}$ is endothelium-dependent [14, 30-33]. These endothelial $\mathrm{K}_{\mathrm{ir}}$ channels can still be modulated by a " $\mathrm{K}^{+}$cloud" thereby amplifying endothelial hyperpolarization which then spreads through the myoendothelial gap junctions. The present study was performed on endothelium-intact arteries making it impossible to distinguish the functional localization of the $\mathrm{Na}^{+}, \mathrm{K}^{+}$-ATPase and $\mathrm{K}_{\mathrm{ir}}$ channels. But regardless of their localization our results indicate that the $\mathrm{Na}^{+}, \mathrm{K}^{+}$-ATPase or $\mathrm{K}_{\mathrm{ir}}$ channels or both are modulated by $\left[\mathrm{Ca}^{2+}\right]_{\text {out }}$ and that they act as sensors for $\left[\mathrm{K}^{+}\right]_{\text {out }}$. The localized $\left[\mathrm{K}^{+}\right]_{\text {out }}$ can act either 


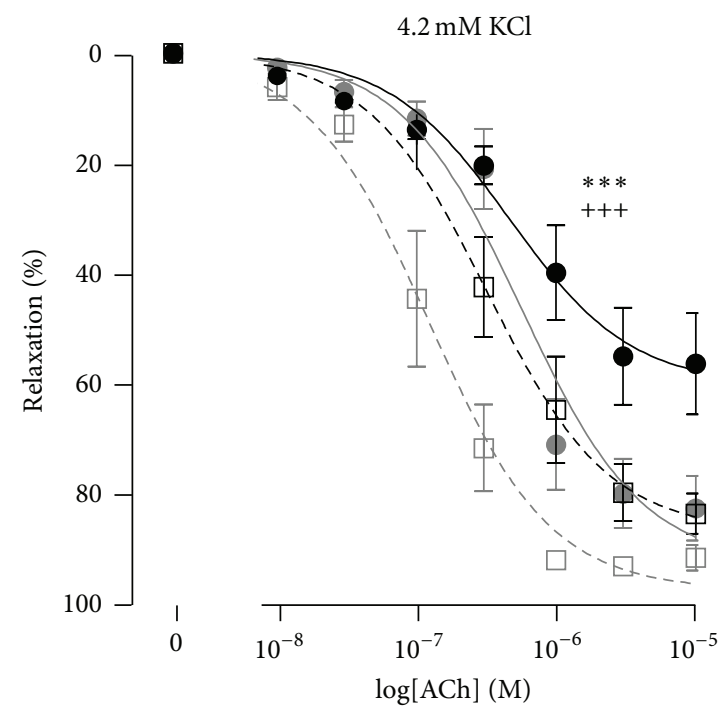

- $1 \mathrm{mM}\left[\mathrm{Ca}^{2+}\right]_{\text {out }}+\mathrm{L}-\mathrm{NAME}$ and indomethacin $\square 2.5 \mathrm{mM}\left[\mathrm{Ca}^{2+}\right]_{\text {out }}+\mathrm{L}-\mathrm{NAME}$ and indomethacin

- $1 \mathrm{mM}\left[\mathrm{Ca}^{2+}\right]_{\text {out }}+\mathrm{L}-\mathrm{NAME}$, indomethacin, and TRAM34

$2.5 \mathrm{mM}\left[\mathrm{Ca}^{2+}\right]_{\text {out }}+\mathrm{L}-\mathrm{NAME}$, indomethacin and, TRAM34

(a)

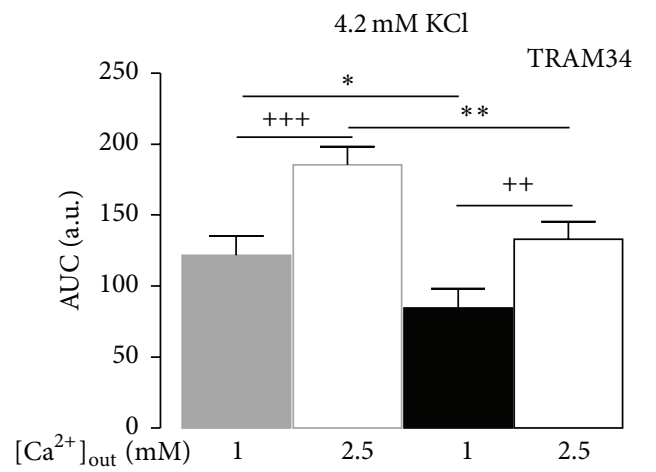

(c)

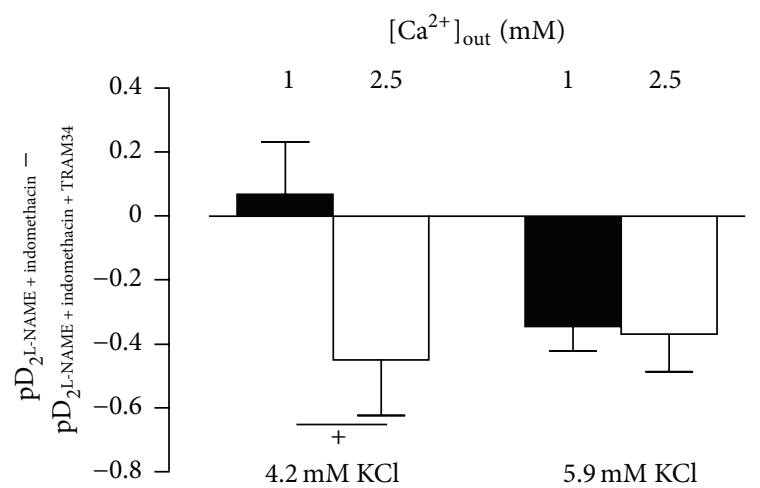

(d)

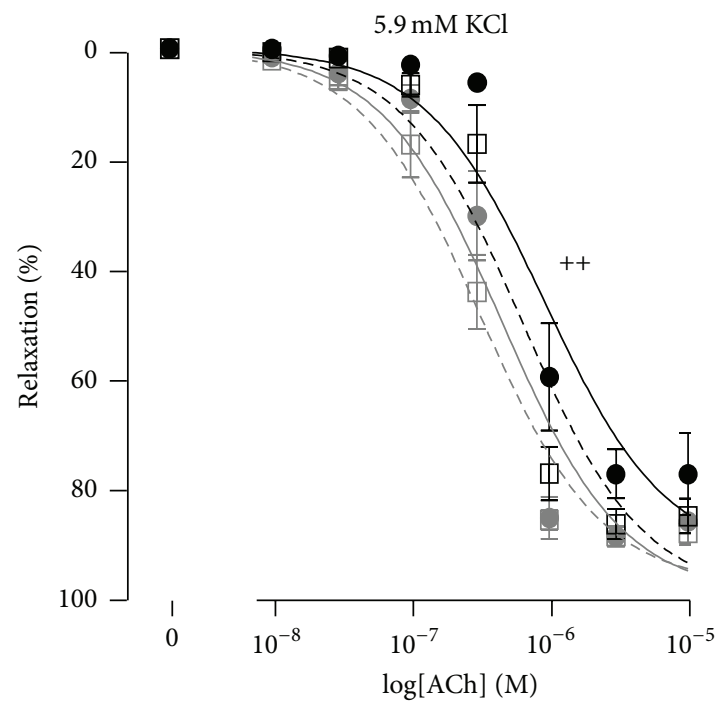

- $1 \mathrm{mM}\left[\mathrm{Ca}^{2+}\right]_{\text {out }}+\mathrm{L}-\mathrm{NAME}$ and indomethacin $\square 2.5 \mathrm{mM}\left[\mathrm{Ca}^{2+}\right]_{\text {out }}+\mathrm{L}-\mathrm{NAME}$ and indomethacin

- $1 \mathrm{mM}\left[\mathrm{Ca}^{2+}\right]_{\text {out }}+\mathrm{L}-\mathrm{NAME}$, indomethacin, and TRAM34

$\square 2.5 \mathrm{mM}\left[\mathrm{Ca}^{2+}\right]_{\text {out }}+\mathrm{L}-\mathrm{NAME}$, indomethacin, and TRAM34

(b)
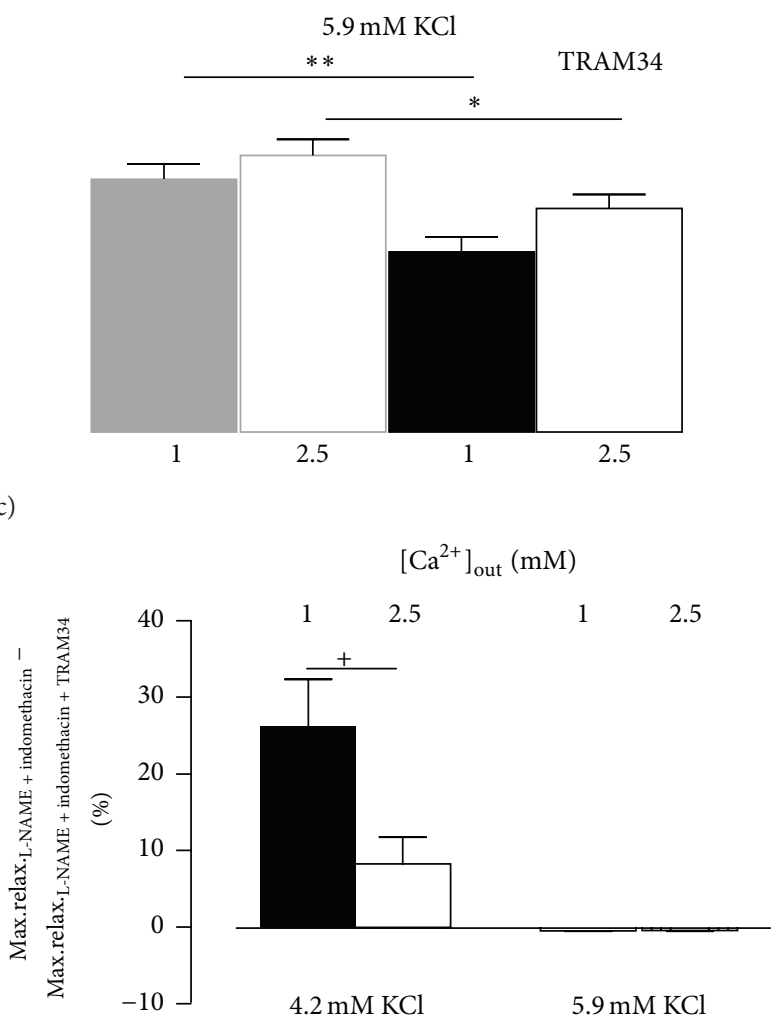

(e)

FIGURE 4: The concentration-dependent relaxation to ACh in the bath solutions containing $4.2 \mathrm{mM}((\mathrm{a}) n=8)$ and $5.9 \mathrm{mM}((\mathrm{b}) n=8)$ $\left[\mathrm{K}^{+}\right]_{\text {out }}$. Responses were compared after preincubation with $100 \mu \mathrm{M} \mathrm{L}-\mathrm{NAME}$ and $3 \mu \mathrm{M}$ indomethacin (grey curves) and after preincubation with $100 \mu \mathrm{M}$ L-NAME, $3 \mu \mathrm{M}$ indomethacin, and $1 \mu \mathrm{M}$ TRAM34 (black curves). (c) shows the areas under curve (AUC) for the concentrationresponse curves shown in (a) and (b). (d) shows a shift in sensitivities to $\mathrm{ACh}\left(\mathrm{pD}_{2}\right)$ after addition of TRAM34 in the experiments shown in (a) and (b). (e) shows changes in the maximal relaxations (to $10 \mu \mathrm{M} \mathrm{ACh}$ ) for the experiments shown in (a) and (b).,+++ , and +++ indicate $P<0.05,0.01$, and 0.001 for responses in the presence of $1 \mathrm{mM}$ versus $2.5 \mathrm{mM}\left[\mathrm{Ca}^{2+}\right]_{\text {out }} * * * *$, and $* * *$ indicate $P<0.05,0.01$, and 0.001 for responses before and after incubation with TRAM34. 


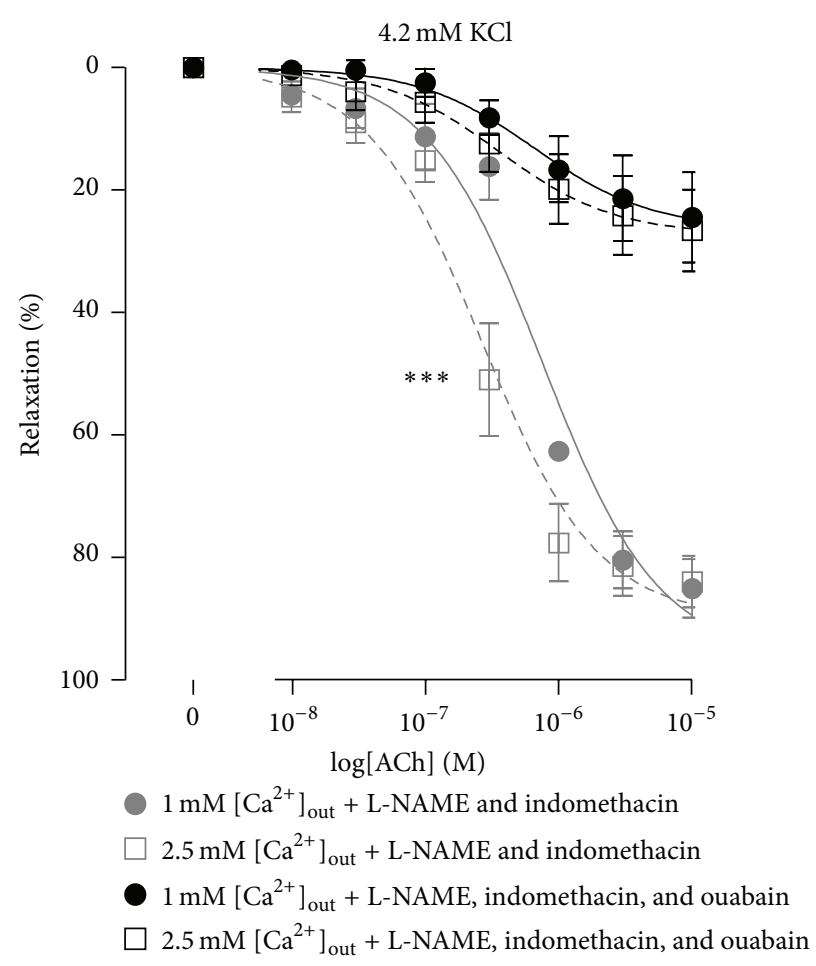

(a)

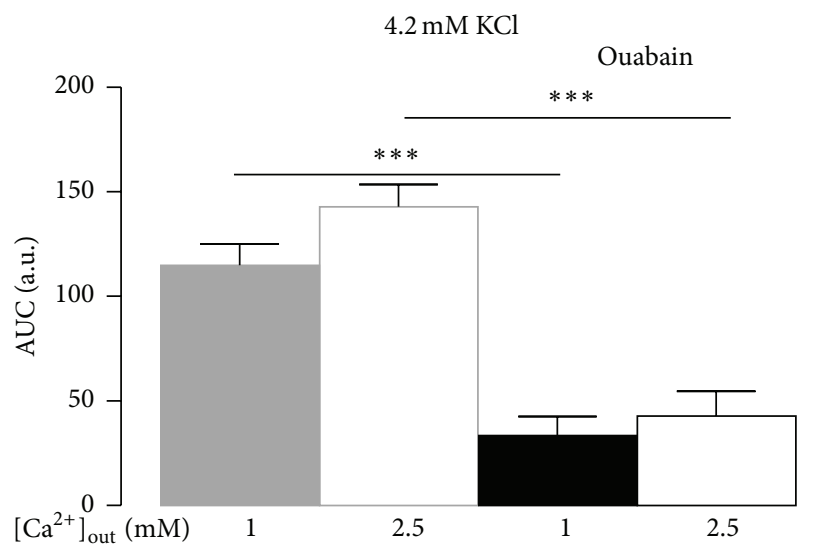

(c)

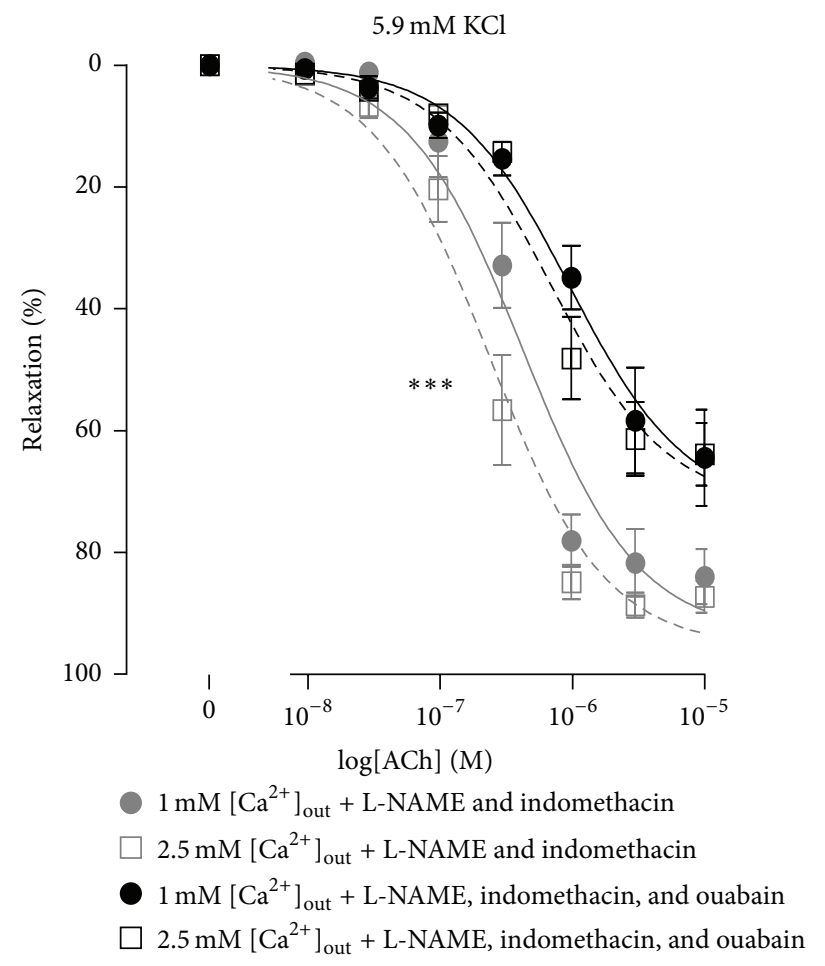

(b)

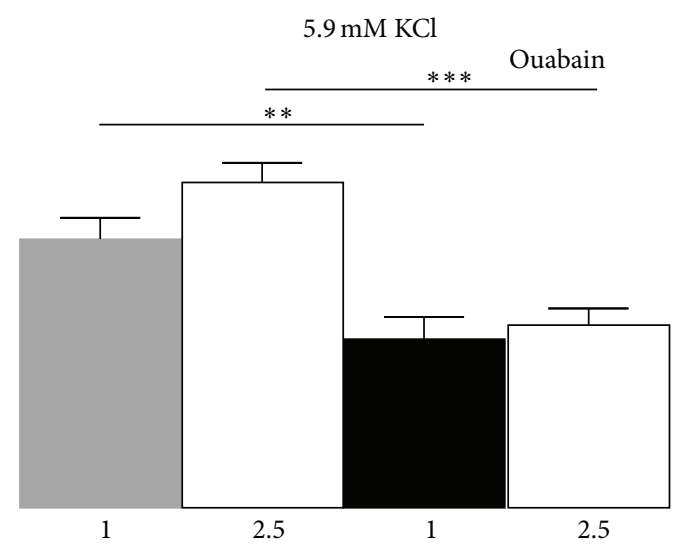

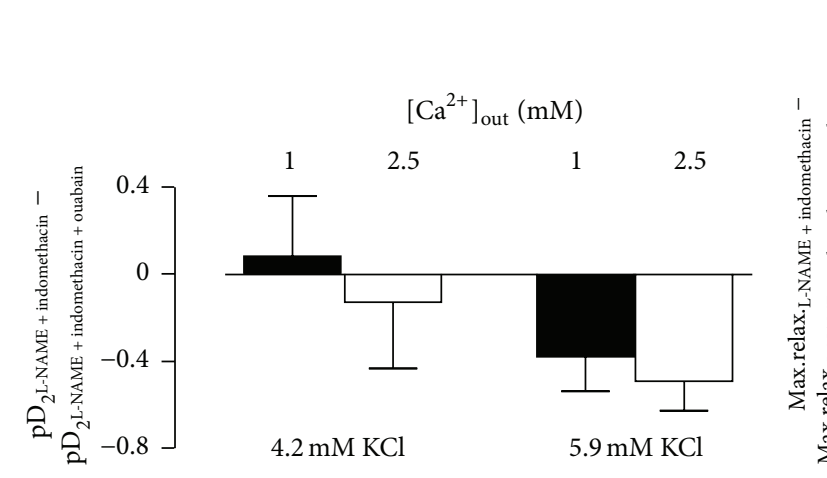

(d)

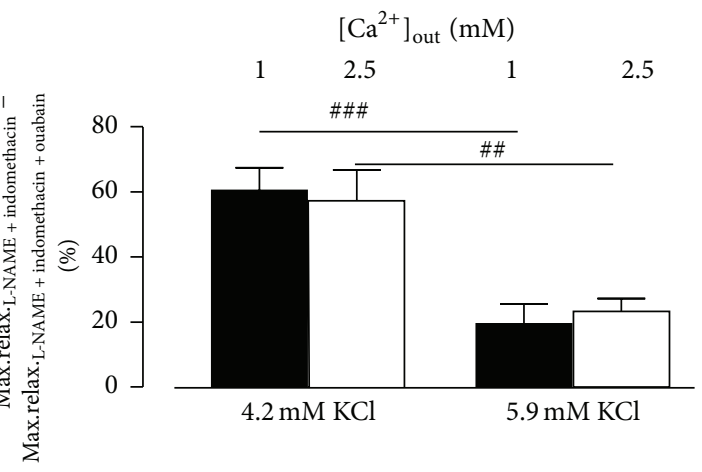

(e)

FIGURE 5: Incubation with $10 \mu \mathrm{M}$ ouabain in the presence of $100 \mu \mathrm{M}$ L-NAME and $3 \mu \mathrm{M}$ indomethacin suppressed ACh-dependent relaxations. The concentration-response curves were constructed for the experiments in the bath solutions containing $4.2 \mathrm{mM}((\mathrm{a}) n=8)$ and $5.9 \mathrm{mM}((\mathrm{b}) n=8)\left[\mathrm{K}^{+}\right]_{\text {out }}$. (c) shows the areas under curves (AUC) from (a) and (b). The changes in sensitivities to $\mathrm{ACh}\left(\mathrm{pD}_{2}\right)$ before and after incubation are shown in (d). The changes in maximal relaxations (to $10 \mu \mathrm{M} \mathrm{ACh}$ ) before and after the treatment with ouabain are shown in (e). $* *$ and $* * *$ indicate $P<0.01$ and 0.001 for the responses before and after incubation with ouabain. \#\# and \#\#\# indicate $P<0.01$ and 0.001 for $4.2 \mathrm{mM}$ versus $5.9 \mathrm{mM}\left[\mathrm{K}^{+}\right]_{\text {out }}$. 

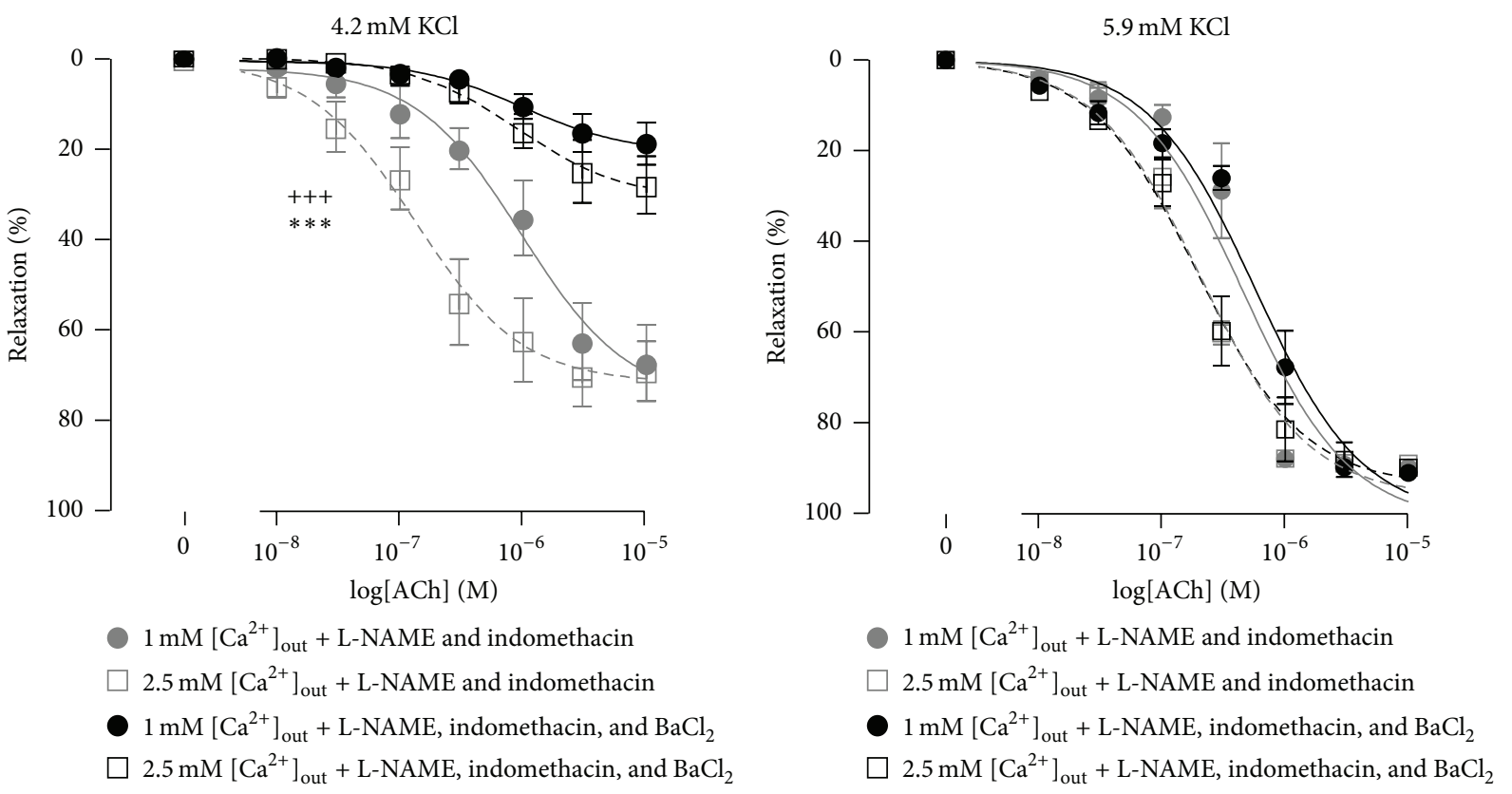

(a)

(b)

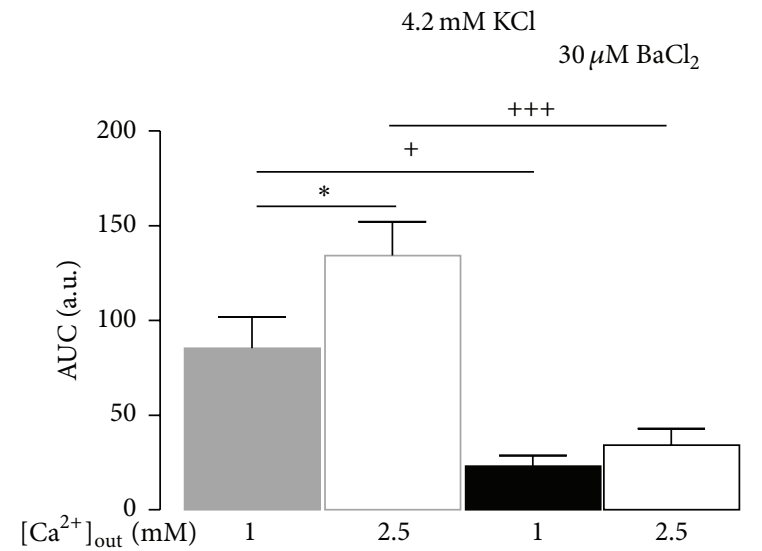

$5.9 \mathrm{mM} \mathrm{KCl}$

$30 \mu \mathrm{M} \mathrm{BaCl}_{2}$

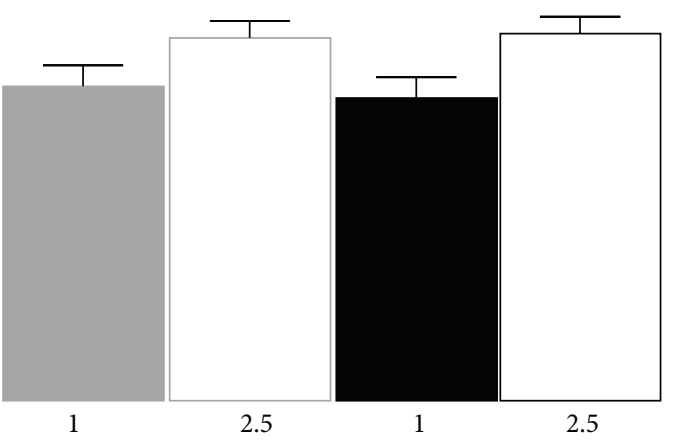

(c)

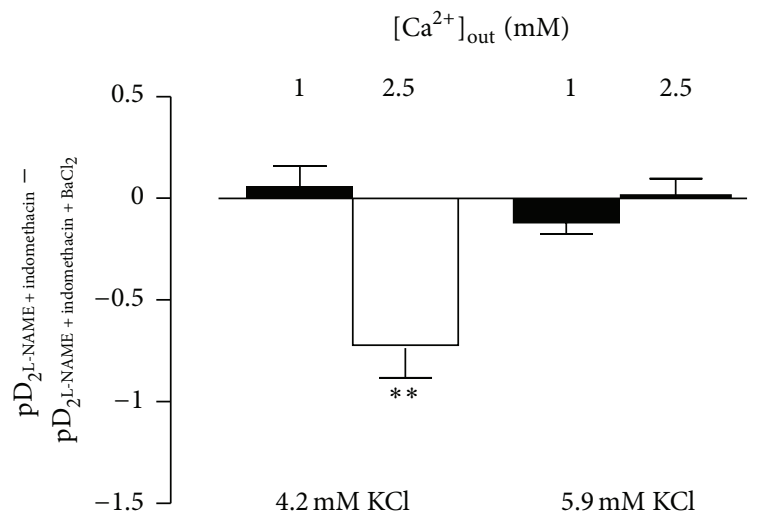

(d)

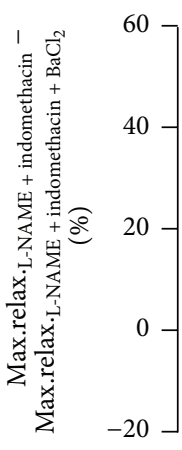

$-20$
$\left[\mathrm{Ca}^{2+}\right]_{\text {out }}(\mathrm{mM})$

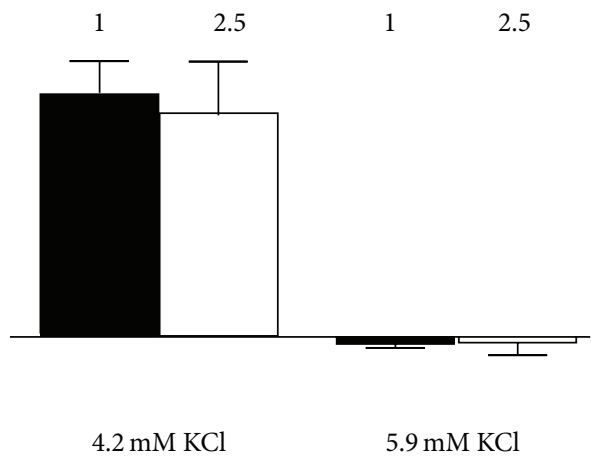

(e)

FIgURE 6: Addition of $30 \mu \mathrm{M} \mathrm{BaCl}$ to the solution containing $100 \mu \mathrm{M} \mathrm{L-NAME}$ and $3 \mu \mathrm{M}$ indomethacin suppressed ACh-dependent relaxations. The concentration-response curves were constructed in the bath solutions with $4.2 \mathrm{mM}((\mathrm{a}) n=6)$ and with $5.9 \mathrm{mM}((\mathrm{b}) n=6)$ $\left[\mathrm{K}^{+}\right]_{\text {out }}$. (c) shows the areas under curves (AUC) as in (a) and (b). Changes in the sensitivities to $\mathrm{ACh}\left(\mathrm{pD}_{2}\right)$ after addition of $\mathrm{BaCl}_{2}$ are shown in (d). The effects of $\mathrm{BaCl}_{2}$ on the maximal relaxations are shown in (e). ** indicates $P<0.01$ versus $1 \mathrm{mM}\left[\mathrm{Ca}^{2+}\right]_{\text {out }}$. 
as EDHF (in case of smooth muscle cell localization of the $\mathrm{K}^{+}$ sensors) or by amplifying the endothelial hyperpolarization which then spreads through the myoendothelial gap junctions (in case of endothelial localization of the $\mathrm{K}^{+}$sensors).

4.3. The Localized $\left[\mathrm{K}^{+}\right]_{\text {out }}$ Signaling. The importance of $\left[\mathrm{Ca}^{2+}\right]_{\text {out }}$ was studied at two concentrations of $\left[\mathrm{K}^{+}\right]_{\text {out }}$. We chose values close to physiological values for rats based on the observation that increase in $\left[\mathrm{K}^{+}\right]_{\text {out }}$ to $5.9 \mathrm{mM}$ induces $\mathrm{BaCl}_{2}$-sensitive relaxation while relaxation to $\left[\mathrm{K}^{+}\right]_{\text {out }}$ above $5.9 \mathrm{mM}$ is diminishing $[13,19,30,34]$. In addition, it has been suggested that the $\mathrm{Na}^{+}, \mathrm{K}^{+}$-ATPase in the vasculature is fully saturated at $5.9 \mathrm{mM}\left[\mathrm{K}^{+}\right]_{\text {out }}[24,35]$. This suggests that any relaxation in the presence of $5.9 \mathrm{mM}\left[\mathrm{K}^{+}\right]_{\text {out }}$ is unlikely to be caused by an increase of $\left[\mathrm{K}^{+}\right]_{\text {out }}$.

This suggestion was supported by our observation that in the presence of $5.9 \mathrm{mM}\left[\mathrm{K}^{+}\right]_{\text {out }}$ ouabain and particularly $\mathrm{Ba}^{2+}$ had a little effect on the relaxation, while at $4.2 \mathrm{mM}$ $\left[\mathrm{K}^{+}\right]_{\text {out }}$ pronounced effects of these inhibitors were seen. This could be because the elevation of $\left[\mathrm{K}^{+}\right]_{\text {out }}$ to $5.9 \mathrm{mM}$ saturates the $\mathrm{Na}^{+}, \mathrm{K}^{+}$-ATPase and $\mathrm{K}_{\mathrm{ir}}$ channels in agonist preconstricted arteries [19]. In fact, the " $\mathrm{K}^{+}$cloud" can be generated not only by the endothelium but also via $\mathrm{K}^{+}$efflux from big-conductance $\mathrm{Ca}^{2+}$-activated $\mathrm{K}^{+}$channels which are activated in depolarized smooth muscle cells of agonist preconstricted arteries [14]. It has previously been shown that, under experimental conditions where the $\mathrm{K}^{+}$-sensors are saturated, inhibition of the $\mathrm{Na}, \mathrm{K}$-pump and $\mathrm{K}_{\mathrm{ir}}$ channels has no effect on relaxation [14]. This indicates that the EDH under these conditions spreads through other mechanisms, possibly as a hyperpolarizing current via myoendothelial gap junctions.

Consistent with this, the modulating effect of $\left[\mathrm{Ca}^{2+}\right]_{\text {out }}$ seen at $4.2 \mathrm{mM}\left[\mathrm{K}^{+}\right]_{\text {out }}$ was abolished at $5.9 \mathrm{mM}\left[\mathrm{K}^{+}\right]_{\text {out }}$. This finding is further consistent with our suggestion that the modulatory function of $\left[\mathrm{Ca}^{2+}\right]_{\text {out }}$ is mediated largely via the $\mathrm{Na}, \mathrm{K}$-pump and $\mathrm{K}_{\mathrm{ir}}$ channels. Finally, the lack of effect of TRAM34 at $5.9 \mathrm{mM}\left[\mathrm{K}^{+}\right]_{\text {out }}$ is consistent with the hypothesis [11] that the importance of the $\mathrm{IK}_{\mathrm{Ca}}$ channels for the $\mathrm{EDH}$ is associated with a localized increase in $\left[\mathrm{K}^{+}\right]_{\text {out }}[12]$ which acts through the $\mathrm{Na}$,K-pump and $\mathrm{K}_{\mathrm{ir}}$ channels.

While no effect of $\mathrm{Ba}^{2+}$ was seen at $5.9 \mathrm{mM}\left[\mathrm{K}^{+}\right]_{\text {out }}$, a small but significant inhibition of the relaxation was observed in the presence of ouabain. If at this $\left[\mathrm{K}^{+}\right]_{\text {out }}$ the $\mathrm{Na}^{+}, \mathrm{K}^{+}$ATPase is completely saturated as suggested [24, 35], it is possible that the observed effect of ouabain was mediated via modulation of gap junctions. It has previously been shown that inhibition of the $\mathrm{Na}^{+}, \mathrm{K}^{+}$-ATPase suppresses intercellular communications, including myoendothelial gap junctions $[22,26,36,37]$. Thus, part of the ouabain effect can be related to inhibition of EDH spreading to smooth muscles through the myoendothelial gap junctions.

\section{Conclusion}

The main findings of this study are as follows: (i) an elevation of $\left[\mathrm{Ca}^{2+}\right]_{\text {out }}$ enhances the EDH-like relaxation to $\mathrm{ACh}$, but (ii) this $\mathrm{Ca}^{2+}$ effect disappears with an elevation of $\left[\mathrm{K}^{+}\right]_{\text {out }}$. (iii) The effect of $\left[\mathrm{Ca}^{2+}\right]_{\text {out }}$ is maintained after blocking the $\mathrm{IK}_{\mathrm{Ca}}$ channels, but (iv) it disappears after blockade of the $\mathrm{Na}^{+}, \mathrm{K}^{+}$-ATPase and $\mathrm{K}_{\text {ir }}$ channels. (v) Finally, inhibitors of the $\mathrm{Na}^{+}, \mathrm{K}^{+}$-ATPase and $\mathrm{K}_{\mathrm{ir}}$ channels, ouabain and $\mathrm{Ba}^{2+}$, have large effect on EDH-like relaxation only when $\left[\mathrm{K}^{+}\right]_{\text {out }}$ is low. Thus, we have suggested that the localized $\left[\mathrm{K}^{+}\right]_{\text {out }}$ signaling acts through the $\mathrm{Na}^{+}, \mathrm{K}^{+}$-ATPase and $\mathrm{K}_{\text {ir }}$ channels, and we have provided strong evidence that these two $\mathrm{K}^{+}$sensors are affected by $\left[\mathrm{Ca}^{2+}\right]_{\text {out }}$.

\section{Conflict of Interests}

The authors declare that there is no conflict of interests regarding the publication of this paper.

\section{Authors' Contribution}

Christian Aalkjaer and Vladimir V. Matchkov contributed equally to this paper.

\section{Acknowledgments}

The authors thank Jørgen Andresen for excellent technical assistance. They thank Professor Michael J. Mulvany, Department of Biomedicine, Aarhus University, for carefully reading the paper. The study was supported by the Danish Research Council, the Novo Nordisk Foundation, and the A.P. Møller Foundation for the Advancement of Medical Science.

\section{References}

[1] C. de Wit and S. E. Wölfle, "EDHF and gap junctions: important regulators of vascular tone within the microcirculation," Current Pharmaceutical Biotechnology, vol. 8, no. 1, pp. 11-25, 2007.

[2] H. Shimokawa, H. Yasutake, K. Fujii et al., "The importance of the hyperpolarizing mechanism increases as the vessel size decreases in endothelium-dependent relaxations in rat mesenteric circulation," Journal of Cardiovascular Pharmacology, vol. 28, no. 5, pp. 703-711, 1996.

[3] S. L. Sandow, "Factors, fiction and endothelium-derived hyperpolarizing factor," Clinical and Experimental Pharmacology and Physiology, vol. 31, no. 9, pp. 563-570, 2004.

[4] C. J. Garland, C. R. Hiley, and K. A. Dora, "EDHF: spreading the influence of the endothelium," British Journal of Pharmacology, vol. 164, no. 3, pp. 839-852, 2011.

[5] G. Edwards, M. Félétou, and A. H. Weston, "Endotheliumderived hyperpolarising factors and associated pathways: a synopsis," Pflügers Archiv - European Journal of Physiology, vol. 459, no. 6, pp. 863-879, 2010.

[6] I. Grgic, B. P. Kaistha, J. Hoyer, and R. Köhler, "Endothelial $\mathrm{Ca}^{2+}$-activated $\mathrm{K}^{+}$channels in normal and impaired EDHFdilator responses-relevance to cardiovascular pathologies and drug discovery," British Journal of Pharmacology, vol. 157, no. 4, pp. 509-526, 2009.

[7] S. L. Sandow, C. B. Neylon, M. X. Chen, and C. J. Garland, "Spatial separation of endothelial small- and intermediateconductance calcium-activated potassium channels $\left(\mathrm{K}_{\mathrm{Ca}}\right)$ and connexins: possible relationship to vasodilator function?" Journal of Anatomy, vol. 209, no. 5, pp. 689-698, 2006. 
[8] G. J. Crane, N. Gallagher, K. A. Dora, and C. J. Garland, "Small- and intermediate-conductance calcium-activated $\mathrm{K}^{+}$ channels provide different facets of endothelium-dependent hyperpolarization in rat mesenteric artery," The Journal of Physiology, vol. 553, no. 1, pp. 183-189, 2003.

[9] R. Busse, G. Edwards, M. Félétou, I. Fleming, P. M. Vanhoutte, and A. H. Weston, "EDHF: bringing the concepts together," Trends in Pharmacological Sciences, vol. 23, no. 8, pp. 374-380, 2002.

[10] A. H. Weston, E. L. Porter, E. Harno, and G. Edwards, "Impairment of endothelial SK Ca channels and of downstream hyperpolarizing pathways in mesenteric arteries from spontaneously hypertensive rats," British Journal of Pharmacology, vol. 160, no. 4, pp. 836-843, 2010.

[11] K. A. Dora, N. T. Gallagher, A. McNeish, and C. J. Garland, "Modulation of endothelial cell KCa3.1 channels during endothelium-derived hyperpolarizing factor signaling in mesenteric resistance arteries," Circulation Research, vol. 102, no. 10, pp. 1247-1255, 2008.

[12] G. Edwards, K. A. Dora, M. J. Gardener, C. J. Garland, and A. H. Weston, " $\mathrm{K}^{+}$is an endothelium-derived hyperpolarizing factor in rat arteries," Nature, vol. 396, no. 6708, pp. 269-272, 1998.

[13] G. Edwards and A. H. Weston, "Potassium and potassium clouds in endothelium-dependent hyperpolarizations," Pharmacological Research, vol. 49, no. 6, pp. 535-541, 2004.

[14] K. A. Dora and C. J. Garland, "Properties of smooth muscle hyperpolarization and relaxation to $\mathrm{K}^{+}$in the rat isolated mesenteric artery," The American Journal of Physiology-Heart and Circulatory Physiology, vol. 280, no. 6, pp. H2424-H2429, 2001.

[15] K. K. Bradley, J. H. Jaggar, A. D. Bonev et al., " $K_{\text {ir }} 2.1$ encodes the inward rectifier potassium channel in rat arterial smooth muscle cells," The Journal of Physiology, vol. 515, no. 3, pp. 639651, 1999.

[16] A. H. Weston, M. Absi, D. T. Ward et al., "Evidence in favor of a calcium-sensing receptor in arterial endothelial cells: studies with calindol and Calhex 231," Circulation Research, vol. 97, no. 4, pp. 391-398, 2005.

[17] M. J. Mulvany and W. Halpern, "Mechanical properties of vascular smooth muscle cells in situ," Nature, vol. 260, no. 5552, pp. 617-619, 1976.

[18] S. Smajilovic and J. Tfelt-Hansen, "Calcium acts as a first messenger through the calcium-sensing receptor in the cardiovascular system," Cardiovascular Research, vol. 75, no. 3, pp. 457-467, 2007.

[19] A. H. Weston, M. Absi, E. Harno et al., "The expression and function of $\mathrm{Ca}^{2+}$-sensing receptors in rat mesenteric artery; comparative studies using a model of type II diabetes," British Journal of Pharmacology, vol. 154, no. 3, pp. 652-662, 2008.

[20] M. Hayashi, C. Kunii, T. Takahata, and T. Ishikawa, "ATPdependent regulation of SK4/IK1-like currents in rat submandibular acinar cells: possible role of cAMP-dependent protein kinase," The American Journal of Physiology-Cell Physiology, vol. 286, no. 3, pp. C635-C646, 2004.

[21] T. von Hahn, I. Thiele, L. Zingaro et al., "Characterisation of the rat SK4/IK1 K ${ }^{+}$channel," Cellular Physiology and Biochemistry, vol. 11, no. 4, pp. 219-230, 2001.
[22] V. V. Matchkov, N. Moeller-Nielsen, V. S. Dam, Z. Nourian, D. M. B. Boedtkjer, and C. Aalkjaer, "The $\alpha_{2}$ isoform of the Na,Kpump is important for intercellular communication, agonistinduced contraction, and EDHF-like response in rat mesenteric arteries," American Journal of Physiology-Heart and Circulatory Physiology, vol. 303, no. 1, pp. H36-H46, 2012.

[23] M. T. Nelson and J. M. Quayle, "Physiological roles and properties of potassium channels in arterial smooth muscle," The American Journal of Physiology-Cell Physiology, vol. 268, no. 4, pp. C799-C822, 1995.

[24] T. A. Longden and M. T. Nelson, "Vascular inward rectifier K+ channels as external $\mathrm{K}^{+}$sensors in the control of cerebral blood flow," Microcirculation, vol. 22, no. 3, pp. 183-196, 2015.

[25] M. Glavind-Kristensen, V. Matchkov, V. B. Hansen, A. Forman, H. Nilsson, and C. Aalkjær, " $\mathrm{K}_{\mathrm{ATP}}$-channel-induced vasodilation is modulated by the $\mathrm{Na}, \mathrm{K}$-pump activity in rabbit coronary small arteries," British Journal of Pharmacology, vol. 143, no. 7, pp. 872-880, 2004.

[26] V. V. Matchkov, H. Gustafsson, A. Rahman et al., "Interaction between $\mathrm{Na}^{+} / \mathrm{K}^{+}$-pump and $\mathrm{Na}^{+} / \mathrm{Ca}^{2+}$-exchanger modulates intercellular communication," Circulation Research, vol. 100, no. 7, pp. 1026-1035, 2007.

[27] T. Haruna, M. Horie, I. Kouchi et al., "Coordinate interaction between ATP-sensitive $\mathrm{K}^{+}$channel and $\mathrm{Na}^{+}, \mathrm{K}^{+}$-ATPase modulates ischemic preconditioning," Circulation, vol. 98, no. 25, pp. 2905-2910, 1998.

[28] W.-G. Ding, L.-P. He, M. Omatsu-Kanbe, and H. Kitasato, "A possible role of the ATP-sensitive potassium ion channel in determining the duration of spike-bursts in mouse pancreatic beta-cells," Biochimica et Biophysica Acta-Biomembranes, vol. 1279, no. 2, pp. 219-226, 1996.

[29] R. Köhler and P. Ruth, "Endothelial dysfunction and blood pressure alterations in $\mathrm{K}^{+}$-channel transgenic mice," Pflügers Archiv-European Journal of Physiology, vol. 459, no. 6, pp. 969976, 2010.

[30] J. M. Doughty, J. P. Boyle, and P. D. Langton, "Potassium does not mimic EDHF in rat mesenteric arteries," British Journal of Pharmacology, vol. 130, no. 5, pp. 1174-1182, 2000.

[31] J. M. Doughty, J. P. Boyle, and P. D. Langton, "Blockade of chloride channels reveals relaxations of rat small mesenteric arteries to raised potassium," British Journal of Pharmacology, vol. 132, no. 1, pp. 293-301, 2001.

[32] D. Harris, P. E. M. Martin, W. H. Evans, D. A. Kendall, T. M. Griffith, and M. D. Randall, "Role of gap junctions in endothelium-derived hyperpolarizing factor responses and mechanisms of $\mathrm{K}^{+}$-relaxation," European Journal of Pharmacology, vol. 402, no. 1-2, pp. 119-128, 2000.

[33] P. S. Lacy, G. Pilkington, R. Hanvesakul, H. J. Fish, J. P. Boyle, and H. Thurston, "Evidence against potassium as an endothelium-derived hyperpolarizing factor in rat mesenteric small arteries," British Journal of Pharmacology, vol. 129, no. 3, pp. 605-611, 2000.

[34] G. R. Richards, A. H. Weston, M. P. Burnham, M. Félétou, P. M. Vanhoutte, and G. Edwards, "Suppression of $\mathrm{K}^{+}$-induced hyperpolarization by phenylephrine in rat mesenteric artery: relevance to studies of endothelium-derived hyperpolarizing factor," British Journal of Pharmacology, vol. 134, no. 1, pp. 1-5, 2001. 
[35] D. X. P. Brochet and P. D. Langton, "Dual effect of initial [K] on vascular tone in rat mesenteric arteries," Pflügers Archiv, vol. 453, no. 1, pp. 33-41, 2006.

[36] P. E. M. Martin, N. S. Hill, B. Kristensen, R. J. Errington, and T. M. Griffith, "Ouabain exerts biphasic effects on connexin functionality and expression in vascular smooth muscle cells," British Journal of Pharmacology, vol. 140, no. 7, pp. 1261-1271, 2003.

[37] V. V. Matchkov, "Mechanisms of cellular synchronization in the vascular wall. Mechanisms of vasomotion," Danish Medical Bulletin, vol. 57, no. 10, Article ID B4191, 2010. 


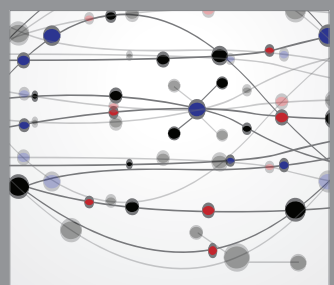

The Scientific World Journal
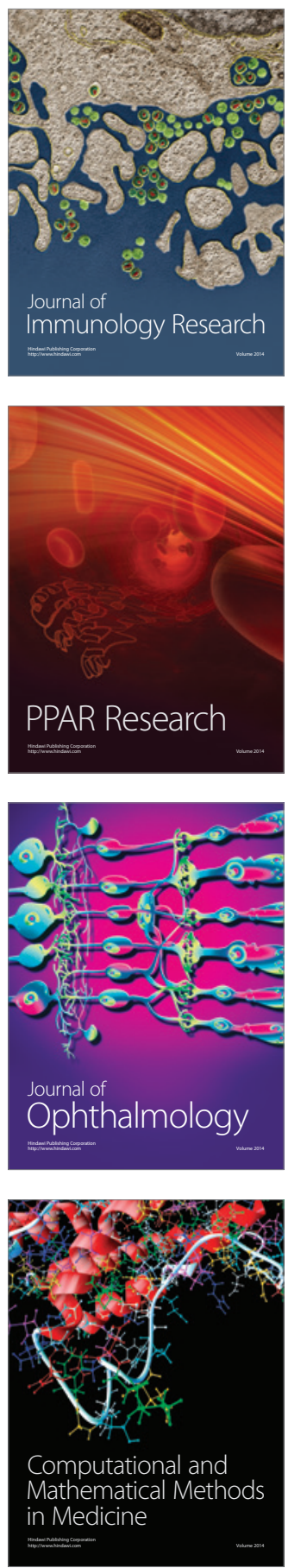

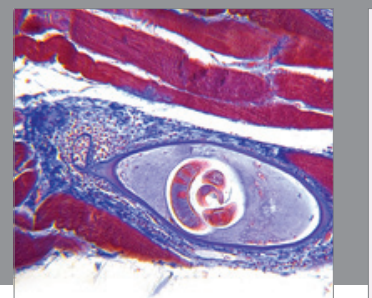

Gastroenterology

Research and Practice
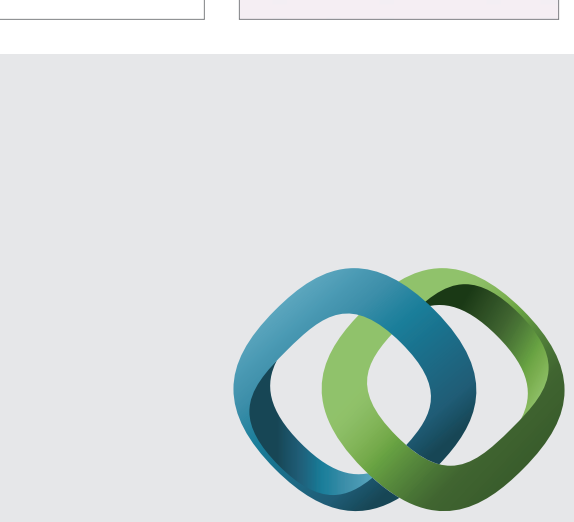

\section{Hindawi}

Submit your manuscripts at

http://www.hindawi.com
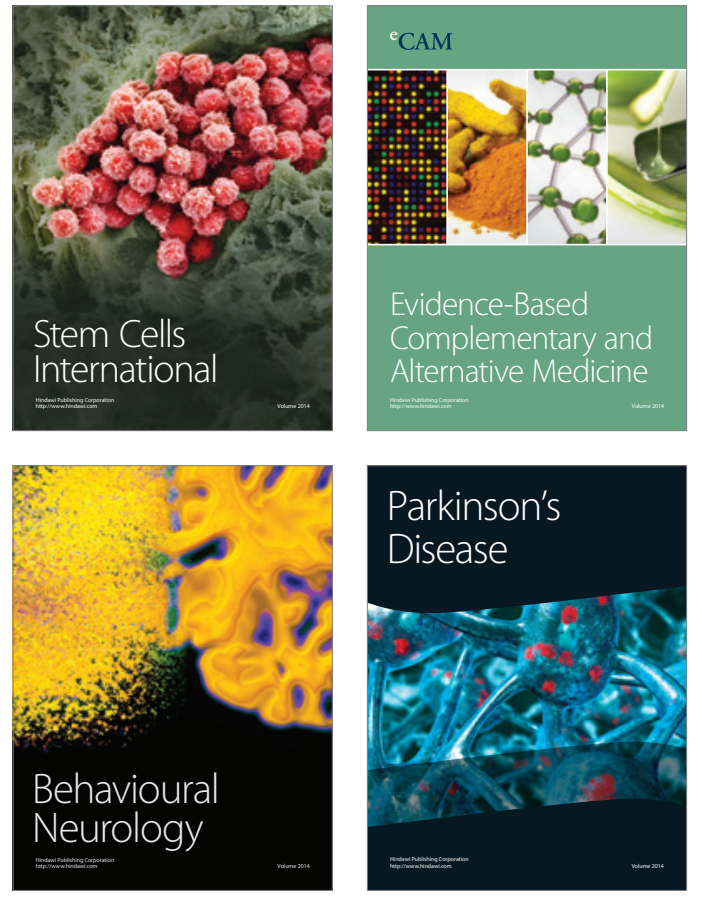
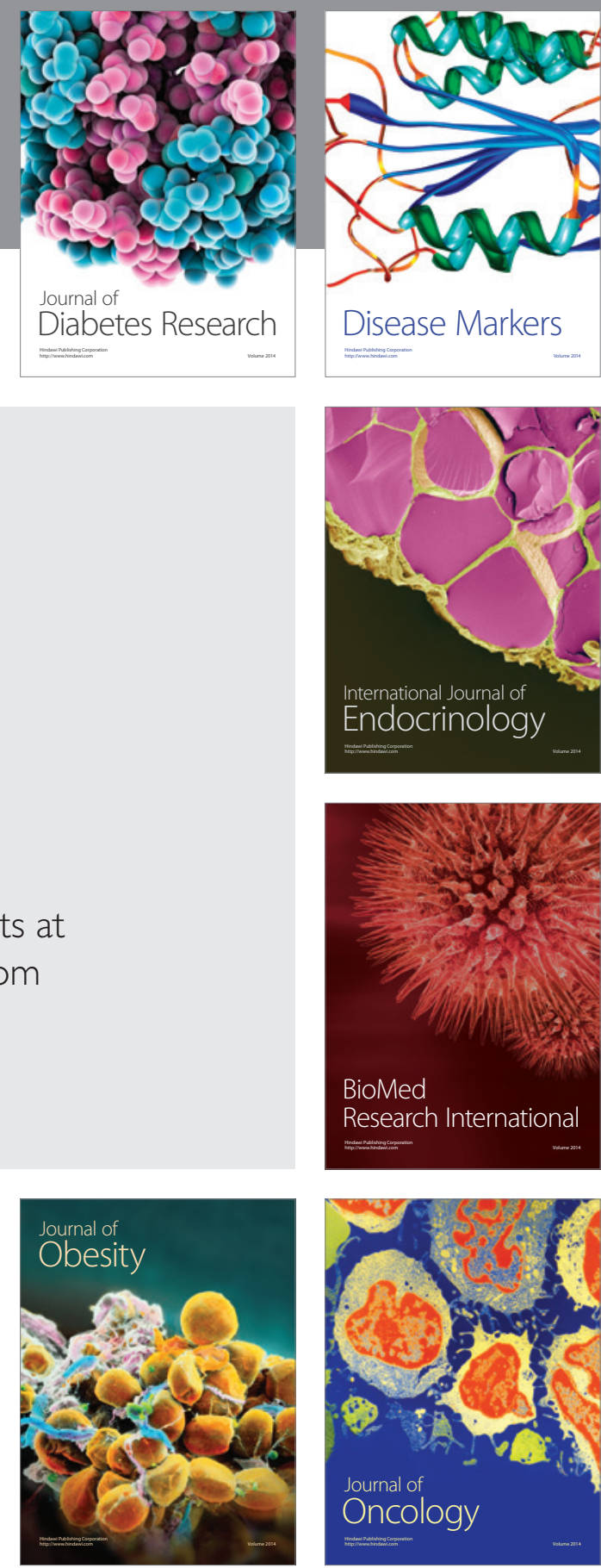

Disease Markers
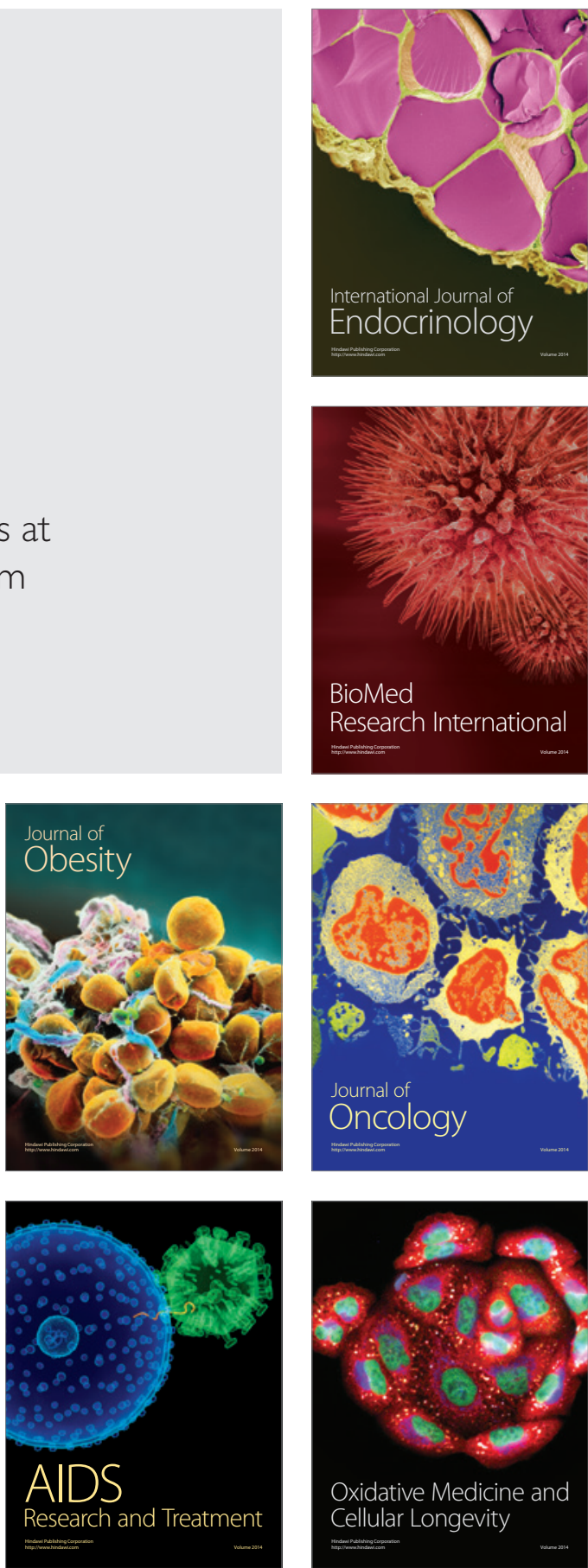